\title{
Transport and mixing patterns over Central California during the carbonaceous aerosol and radiative effects study (CARES)
}

\author{
J. D. Fast ${ }^{1}$, W. I. Gustafson Jr. ${ }^{1}$, L. K. Berg ${ }^{1}$, W. J. Shaw ${ }^{1}$, M. Pekour ${ }^{1}$, M. Shrivastava ${ }^{1}$, J. C. Barnard ${ }^{1}$, \\ R. A. Ferrare ${ }^{2}$, C. A. Hostetler ${ }^{2}$, J. A. Hair ${ }^{2}$, M. Erickson ${ }^{3}$, B. T. Jobson ${ }^{3}$, B. Flowers ${ }^{4}$, M. K. Dubey ${ }^{4}$, S. Springston ${ }^{5}$, \\ R. B. Pierce ${ }^{6}$, L. Dolislager ${ }^{7}$, J. Pederson ${ }^{7}$, and R. A. Zaveri ${ }^{1}$ \\ ${ }^{1}$ Pacific Northwest National Laboratory, Richland, Washington, USA \\ ${ }^{2}$ NASA Langley Research Center, Hampton, Virginia, USA \\ ${ }^{3}$ Washington State University, Pullman, Washington, USA \\ ${ }^{4}$ Los Alamos National Laboratory, Los Alamos, New Mexico, USA \\ ${ }^{5}$ Brookhaven National Laboratory, Upton, New York, USA \\ ${ }^{6}$ NOAA National Environmental Satellite, Data, and Information Service, Madison, Wisconsin, USA \\ ${ }^{7}$ California Air Resources Board, Sacramento, California, USA
}

Correspondence to: J. D. Fast (jerome.fast@pnl.gov)

Received: 19 October 2011 - Published in Atmos. Chem. Phys. Discuss.: 8 November 2011

Revised: 19 January 2012 - Accepted: 6 February 2012 - Published: 17 February 2012

\begin{abstract}
We describe the synoptic and regional-scale meteorological conditions that affected the transport and mixing of trace gases and aerosols in the vicinity of Sacramento, California during June 2010 when the Carbonaceous Aerosol and Radiative Effects Study (CARES) was conducted. The meteorological measurements collected by various instruments deployed during the campaign and the performance of the chemistry version of the Weather Research and Forecasting model (WRF-Chem) are both discussed. WRF-Chem was run daily during the campaign to forecast the spatial and temporal variation of carbon monoxide emitted from 20 anthropogenic source regions in California to guide aircraft sampling. The model is shown to reproduce the overall circulations and boundary-layer characteristics in the region, although errors in the upslope wind speed and boundary-layer depth contribute to differences in the observed and simulated carbon monoxide. Thermally-driven upslope flows that transported pollutants from Sacramento over the foothills of the Sierra Nevada occurred every afternoon, except during three periods when the passage of mid-tropospheric troughs disrupted the regional-scale flow patterns. The meteorological conditions after the passage of the third trough were the most favorable for photochemistry and likely formation of secondary organic aerosols. Meteorological measurements and model forecasts indicate that the Sacramento pollutant plume was likely transported over a downwind site that col-
\end{abstract}

lected trace gas and aerosol measurements during 23 time periods; however, direct transport occurred during only eight of these periods. The model also showed that emissions from the San Francisco Bay area transported by intrusions of marine air contributed a large fraction of the carbon monoxide in the vicinity of Sacramento, suggesting that this source likely affects local chemistry. Contributions from other sources of pollutants, such as those in the Sacramento Valley and San Joaquin Valley, were relatively low. Aerosol layering in the free troposphere was observed during the morning by an airborne Lidar. WRF-Chem forecasts showed that mountain venting processes contributed to aged pollutants aloft in the valley atmosphere that are then entrained into the growing boundary layer the subsequent day.

\section{Introduction}

There are still relatively large uncertainties associated with spatial and temporal variability of predicted aerosol properties from both air quality (e.g. Yu et al., 2008; Mathur et al., 2008; Mangold et al., 2011) and climate models (e.g. Solomon et al., 2007). For example, the complex processes controlling secondary organic aerosols (SOA) and their optical and hygroscopic properties are not known definitively (Jimenez et al., 2009; Vaden et al., 2011) and therefore it has 
been difficult to parameterize and simulate organic aerosol components accurately for the correct reasons (e.g. Volkamer et al., 2006). Global (e.g. Kinne et al., 2006) and regional (e.g. McKeen et al., 2007, 2009) model inter-comparison studies have revealed a wide range of predictions in the magnitude and the diurnal variations of aerosols that can be attributed to many sources. Regional-scale predictions of aerosol mass are not well correlated with observations when paired in space and time and there is a positive bias during the winter (Mathur et al., 2008). Biases in simulated aerosol mass also vary geographically, such as the differences between the eastern and western US (Kang et al., 2010).

One reason for the geographic variations in model performance is that topography may not be adequately resolved, which affects local heating and cooling at the ground and consequently the simulated low-level winds and turbulent mixing. Thermally-driven circulations associated with complex terrain can lead to more variability in trace gas and aerosol distributions than those over relatively flat terrain. Evaluating models in areas of complex terrain, such as the western US, also becomes problematic because measurements from a monitoring site may not be representative of the entire area encompassed by a model grid cell.

Several field campaigns have been conducted in California to evaluate and improve air quality model predictions, including the Southern California Air Quality Study (SCAQS) conducted in August 1987 (e.g. Lawson, 1990), the San Joaquin Valley Air Quality Study (SJVAQS)/Atmospheric Utility Signatures Predictions and Experiments Study (AUSPEX) Regional Modeling Adaptation Project (SARMAP) during August 1990 (e.g. Lagarias and Sylte, 1991), the Southern California Ozone Study (SCOS) between June and October of 1997 (e.g. Croes and Fujita, 2003), the Central California Ozone Study (CCOS) during July and August 2000, and most recently the Arctic Research of the Composition of the Troposphere from Aircraft and Satellites (ARCTAS) that was also conducted over California during June 2008 (Jacob et al., 2010). The focus of these campaigns was to collect meteorological and trace gas measurements to study oxidants; therefore, concurrent measurements of detailed aerosol properties were generally not collected.

Modeling studies utilizing data collected by these field campaigns (e.g. Seaman et al., 1995; Dabub et al., 1999; Jacobson, 2001; Bao et al., 2008; Jin et al., 2010; Huang et al., 2010; Michelson et al., 2010; Pfister et al., 2011) have improved the understanding of how meteorological processes in California affect the spatial variations and chemical transformation of pollutants. Various routine measurements and several special studies in the Central Valley of California have shown that pollutants emitted from Sacramento, California during the summer are frequently transported by the thermally-driven upslope flows that draw the urban air towards the northeast over the foothills of the Sierra Nevada (Murphy et al., 2006). This corridor downwind of Sacramento effectively serves as a mesoscale daytime flow reac- tor in which urban aerosols age due to coagulation, condensation, and photochemical processes. Agricultural land use surrounds Sacramento on the valley floor, while oak and pine tree species are more common over the lower and upper elevations, respectively, of the Sierra Nevada. Anthropogenic trace gas precursors transported over the foothills will eventually mix with biogenic emissions, possibly enhancing SOA production (e.g. Weber et al. 2007). The proximity of the anthropogenic and biogenic emissions coupled with the consistent wind patterns that simplify the logistics of sampling trace gases and aerosols were the reasons the Carbonaceous Aerosol and Radiative Effects Study (CARES), supported by the US Department of Energy, was conducted in the vicinity of Sacramento during June 2010. The science objectives of the campaign were to obtain measurements that:

1. Investigate SOA formation from anthropogenic and biogenic precursors and the potential interaction between them,

2. Characterize time scales of black carbon aging and quantify the relative contributions of condensation and coagulation to black carbon mixing state evolution, and

3. Quantify the effect of aerosol mixing state (i.e. externally or internally mixed) and the role of organics on the associated optical and cloud condensation nuclei $(\mathrm{CCN})$ activation properties.

Zaveri et al. (2011) describes the rationale for CARES as well as the participants, sampling sites and platforms, specific trace gas and aerosol instrumentation, and initial findings.

In this paper we describe the meteorological sampling strategy for CARES, the overall meteorological conditions that controlled the transport, mixing, and transformation of aerosols in the vicinity of Sacramento, and the performance of an operational mesoscale model in simulating the local winds, temperature, humidity, and boundary layer height. Carbon monoxide (CO) emissions were tagged by source in the model and the forecasted $\mathrm{CO}$ is used to illustrate transport and mixing patterns and identify likely anthropogenic emission sources that influenced trace gas and aerosol measurements at the surface sites and along aircraft flight paths. Both the field data and operational forecasts are then used to define periods in which transport from the urban to the rural site likely occurred. The model is also used to identify the primary meteorological processes responsible for aerosol layers observed in the free atmosphere over Sacramento during CARES. The meteorological context provided by this study will inform and support subsequent analyses of the observed trace gases and aerosols performed by other researchers. 

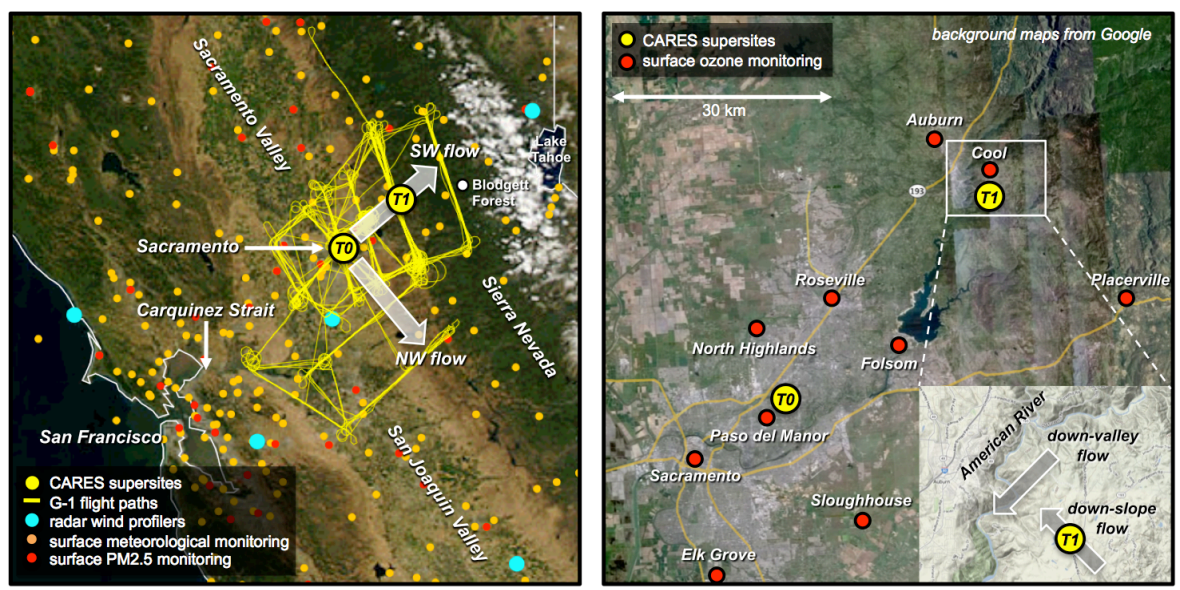

Fig. 1. Locations of the primary surface sampling sites, T0 and T1, in relation to the G-1 flight paths (yellow lines) during CARES. Blue

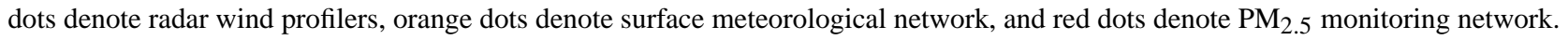

\section{Meteorological sampling}

A wide range of instruments was deployed at two ground sites, T0 and T1, during CARES that continuously measured trace gases and aerosol properties between 2 and 28 June 2010 as described in Zaveri et al. (2011). Meteorological instrumentation was also deployed at each site to quantify winds, temperature, and humidity that affect the evolution of aerosols in the region. As shown in Fig. 1, the T0 site $\left(38.65^{\circ} \mathrm{N}, 121.35^{\circ} \mathrm{W}\right)$ was located about $15 \mathrm{~km}$ northeast of downtown Sacramento on the American River College campus at an elevation of $30 \mathrm{~m}$. The $\mathrm{T} 1$ site $\left(38.87^{\circ} \mathrm{N}\right.$, $121.02^{\circ} \mathrm{W}$ ) was located just south of Cool, a small town $40 \mathrm{~km}$ northeast of $\mathrm{T} 0$, at an elevation of $\sim 460 \mathrm{~m}$ in the foothills of the Sierra Nevada. The names of the sites stand for "time 0" and "time 1" for the expected downwind transport from Sacramento to Cool, adopting the names of surface sites during the MILAGRO campaign (Molina et al., 2010). Figure 1 also shows the locations of surface stations where hourly-averaged meteorological and air-quality data are made available through the California Air Resources Board website (http://www.arb.ca.gov/aqmis2/aqmis2.php).

West of Lake Tahoe is the Blodgett Forest site where the Biosphere Effects on AeRosols and Photochemistry Experiment (BEARPEX) was conducted between 2007 and 2009 that collected a wide range of meteorological, trace gas, and aerosol measurements (e.g. Bouvier-Brown, 2009). Although this site did not operate during CARES, analysis of data from BEARPEX data coupled with CARES data should provide insights into aerosol aging of the Sacramento plume as it mixes with biogenic sources of aerosols and aerosol precursors.

The T1 site was selected based on an analysis of meteorological and trace gas measurements collected by CARB over a 5-year period between 2005 and 2009 during the month of June. As shown in Table 2, peak ozone mixing ratios usu- ally occurred at progressively later times of the afternoon the farther the site was located northeast of central Sacramento, suggesting that the observed southwesterly upslope winds transported ozone produced in Sacramento over the foothills of the Sierra Nevada. For example, peak ozone occurred on average between 13:00 and 14:00 LST at the Sacramento and Del Paso Manor stations, at 15:00 LST at the Roseville and Folsom stations, and at 17:00 LST as the Auburn and Cool stations (Fig. 1). Timing of the peak ozone mixing ratios varied somewhat from year to year, likely affected by ambient meteorological conditions. We also used a Lagrangian particle dispersion modeling system, FLEXPARTWRF (Doran et al., 2009) prior to the campaign to quantify the diurnal variability of scalars that were unaffected by photochemical transformation during June of 2008. Peak surface concentrations of the passive scalars occurred on average at 14:00 LST in Roseville, 17:00 LST at Cool, and 20:00 LST at the Blodgett Forest site, similar to the climatological analysis of ozone in Table 2. On days with southwesterly winds, transport times between the Sacramento area and Cool were between 2 and $8 \mathrm{~h}$ with the shorter transport times associated with particles emitted over the eastern suburbs and the longer transport times associated with particles emitted from downtown Sacramento. Based on these analyses, the T1 site was located near Cool so that aerosols emitted from Sacramento would undergo aging over a few hours before sunset (at $\sim 20: 30$ LST during June).

Both surface sites were equipped with a meteorological station to obtain measurements of wind speed and direction, temperature, pressure, and humidity at 1-min intervals. Radiosondes were launched 5 times per day (08:00, 11:00, 13:00, 15:00 and 17:00 LST) to obtain profiles of pressure, temperature, and humidity in the troposphere at both sites on days when the G-1 aircraft (Zaveri et al., 2011) was sampling. On other days, radiosondes were released once a day 
Table 1. Selected WRF-Chem configuration options used for this study.

\begin{tabular}{ll}
\hline Atmospheric Process & Option \\
\hline Advection & Monotonic \\
Longwave Radiation & RRTM \\
Shortwave Radiation & Goddard \\
Surface Layer & $\begin{array}{l}\text { Monin-Obukhov (Janic) } \\
\text { similarity theory }\end{array}$ \\
Land Surface & Noah \\
Boundary Layer & Mellor-Yamada-Janic \\
Cumulus Convection & Grell 3-D Ensemble \\
Cloud Microphysics & Thompson \\
\hline
\end{tabular}

at 13:00 LST. After the campaign, the convective boundary layer depth was derived from the radiosonde data by examining the vertical gradients in both potential temperature and humidity. Hourly-averaged wind profiles over the Central Valley were obtained from a radar wind profiler, operated by the Sacramento Metropolitan Air Quality Management District, located $\sim 35 \mathrm{~km}$ south-southwest of T0 (Fig. 1). While the range gates of the radar wind profiler extend up to $\sim 5.2 \mathrm{~km}$ a.g.l., range gates near $2.0 \mathrm{~km}$ a.g.l. have missing data $32 \%$ of the time and the percentage of missing data increases to over $74 \%$ above $3.0 \mathrm{~km}$ a.g.l. A sodar deployed at the $\mathrm{T} 1$ site obtained wind profiles at half-hour intervals over the foothills of the Sierra Nevada. The range gates from the sodar extended up to $500 \mathrm{~m}$ AGL at 20-m increments, with missing data $20 \%$ of the time or less within $140 \mathrm{~m}$ of the surface. A $915-\mathrm{mHz}$ radar wind profiler was also deployed at the T1 site that collected data only during the last week of the field campaign. Solar radiation was measured by a pyranometer (Eppley PSP) and a multi-filter rotating shadowband radiometer (MFRSR) deployed at the T1 site and at McClellan Airport where the research aircraft were based, about $5 \mathrm{~km}$ west-northwest of T0. Radiation instruments were not deployed at the T0 site because nearby trees would have obstructed the viewing angle. Instead, they were deployed near one of the airport runways that had unobstructed views of the horizon.

In addition to extensive trace gas and aerosol property measurements, the G-1 aircraft also collected pressure, wind, temperature, and humidity data aloft at 1-s (or shorter) intervals along the flight paths depicted in Fig. 1. Flights generally occurred either during the morning (08:00-12:00 LST) or the late afternoon (14:00-18:00 LST) at altitudes usually between 0.4 and $2.5 \mathrm{~km}$ m.s.l. NASA's B-200 King Air research aircraft, equipped with a High Spectral Resolution Lidar (HSRL) (Hair et al., 2008), obtained measurements of aerosol backscatter, extinction, and depolarization over central California and along most of the same flight paths as the G-1.
These meteorological data, along with the other measurements collected during the campaign, are available through the DOE's ARM climate Research Facility archive (http: //www.archive.arm.gov). In this study we also employ CO measurements. $\mathrm{CO}$ was measured by resonance fluorescence instruments on the G-1 and at T0, and by a Teledyne Gas Correlation absorption spectrometer at $\mathrm{T} 1$.

\section{Operational forecasting}

The WRF-Chem model (Grell et al., 2005; Fast et al., 2006) was run operationally during the field campaign to help plan aircraft flight operations up to three days in advance by simulating the transport and mixing of the Sacramento pollutant plume. The model domain encompassed all of California, western Nevada, and the adjacent Pacific Ocean using a horizontal grid spacing of $4 \mathrm{~km}$. A stretched vertical coordinate system that extended up to $16-20 \mathrm{~km}$ a.g.1. employed 65 grid levels, with a 30-m grid spacing adjacent to the surface and 43 nodes located within $2 \mathrm{~km}$ of the ground. The specific physics parameterizations used for various atmospheric processes available in the public release of the WRF code are listed in Table 1. These parameterizations, commonly employed by the WRF community, were also chosen based on their overall performance for previous applications of WRF we have conducted. A time step of $12 \mathrm{~s}$ was used, which was sufficiently small so that numerical instabilities did not develop for the forecasts during the campaign.

72-h forecasts initialized at 00:00 UTC (16:00 LST) were produced once per day. Initial and boundary conditions for the meteorological variables were based on analyses from the National Center for Environmental Prediction's North American Mesoscale (NAM) model. As will be shown later, the forecasted winds were predicted reasonably well. There are three likely explanations: (1) the domain size (2) terraininduced forcing, and (3) mostly sunny conditions. While the domain encompasses all of California, it is still sufficiently small so that the boundary conditions influence the predicted ambient conditions above the boundary layer over the interior of the domain. The local terrain leads to circulations that are predictable and consistent from day-to-day in the absence of clouds. Mesoscale models are known to have larger forecast errors during periods of clouds and precipitation; however, mostly clear skies were occurred over much of California throughout June 2010.

Trace gas and aerosol variables were not included in the operational forecasts because the primary purpose was to provide estimates of the evolving transport and mixing of pollutant plumes and the relative contribution of local and more distant sources. The computational expense of simulations that included chemical processes would have also prevented 72 -h forecasts from being available each morning to brief the aircraft crew. The model was configured to simulate 20 carbon monoxide (CO) tracers tagged by emission 
Table 2. Time of day (LST) in which peak ozone mixing ratio occurs most frequently during the month of June for stations shown in Fig. 1. Multiple hours are listed when the frequency of occurrence differs by one or zero.

\begin{tabular}{lrrrrr}
\hline Monitoring Station & 2005 & 2006 & 2007 & 2008 & 2009 \\
\hline Sacramento & 15 & 13 & $14-15$ & 14 & 13 \\
Paso Del Manor & 16 & 14 & 14 & 15 & $13-14$ \\
Sloughhouse & 14 & 14 & 16 & 15 & 14 \\
Elk Grove & 15 & 13 & 14 & 14 & 14 \\
Folsom & $15-16$ & 15 & $14-15$ & 15 & 15 \\
Roseville & $14-16$ & 15 & 15 & 15 & 15 \\
Auburn & $16-17$ & 17 & 18 & 17 & 17 \\
Cool & $16-17$ & 17 & 17 & $16-17$ & 17 \\
Placerville & $15-16$ & 17 & 18 & 18 & 16 \\
\hline
\end{tabular}

source region using hourly emission rates available at a 4$\mathrm{km}$ grid spacing developed by the California Air Resources Board (A. Kaduwela, personal communication, 2010) for the NASA Arctic Research of the Composition of the Troposphere from Aircraft and Satellite (ARCTAS) mission over California (Pfister et al., 2011). Figure 2 depicts those grid cells with emission rates above a threshold value of 0.05 moles $\mathrm{CO} \mathrm{s}^{-1}$ cell $^{-1}$, which was $\sim 84$ times lower than the maximum rate. Emissions in grid cells below this threshold were neglected and the simulations assume that they do not contribute significantly to $\mathrm{CO}$ in the vicinity of Sacramento. Separate tracers were used for central Sacramento, the eastern suburbs, the Auburn area in the foothills northeast of Sacramento, and the Placerville area in the foothills east of Sacramento. Two tracers represented the emissions from small cities over rest of the Sierra Nevada. Emissions in the Sacramento Valley and San Joaquin Valley were divided into four and six tracers, respectively, while the entire San Francisco Bay region was treated as one $\mathrm{CO}$ tracer source. The remaining three $\mathrm{CO}$ tracers were divided into three source regions over southern California. The 20 source regions are also grouped into eight larger geographic sources, denoted by the color shading in Fig. 2, used in the analyses presented later.

Emissions from fires were not included in the operational forecasts. Only a few fires were observed by satellites (e.g. MODIS hotspot data) in the vicinity of Sacramento during the campaign.

Initial $\mathrm{CO}$ conditions for each forecast were based on the 24-h forecast from the previous day and boundary conditions were set to very low, constant values of $1.0 \mathrm{e}-9 \mathrm{ppb}$. In reality, background $\mathrm{CO}$ mixing ratios are likely to vary in time as a result of long-range transport from Asia (e.g. Jaffe et al., 1999; Huang et al., 2010). WRF-Chem was not coupled with a global model prediction system since the primary purpose was to predict plume locations to guide aircraft operations rather than simulate exact magnitudes. To compare the WRF-Chem forecasts with measurements, background CO mixing ratios need to be included. Time-varying background

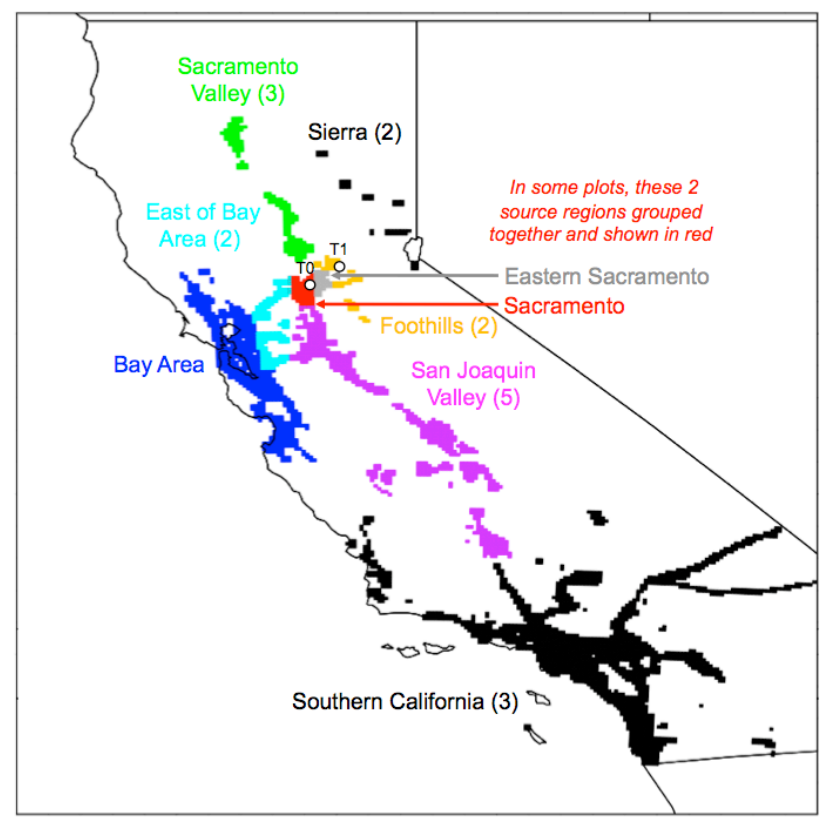

Fig. 2. Spatial distribution of the $\mathrm{CO}$ tracer source regions employed by the operational WRF-Chem forecasts during CARES. A total of 20 source regions were defined, but colors denote larger geographic source regions used in subsequent plots, where the parentheses indicates the number of source regions grouped together per color.

CO mixing ratios in the Sacramento region were estimated by taking the difference between two regional-scale simulations from the coupled North American Mesoscale (NAM) Community Multiscale Air Quality (CMAQ) modeling system (Otte et al., 2005): one in which the boundary conditions were obtained from the Real-time Air Quality Modeling System (RAQMS) (Pierce et al., 2007) and one which used fixed boundary conditions. These NAM-CMAQ simulations were run using a parallel version of the Operational NAM-CMAQ that was being tested during the Research at the Nexus of Air Quality and Climate Change experiment 
(a) 12 2ure rumes

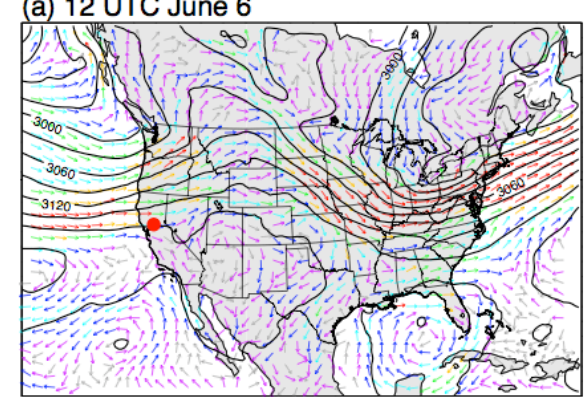

(c) 12 UTC June 14

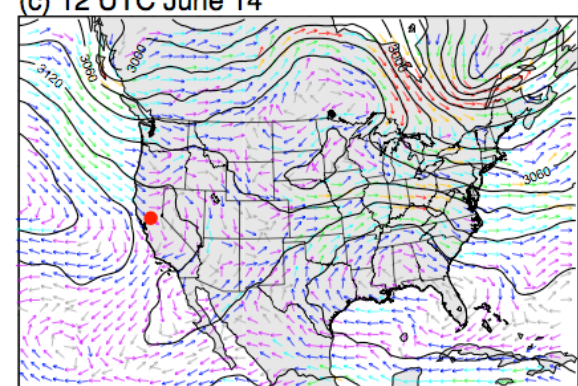

(e) 12 UTC June 18

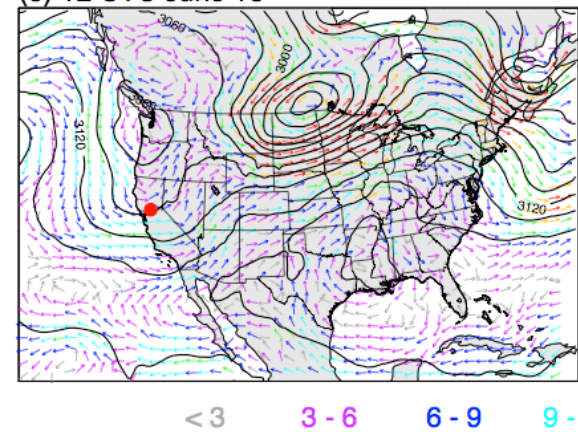

(b) 12 UTC June 11

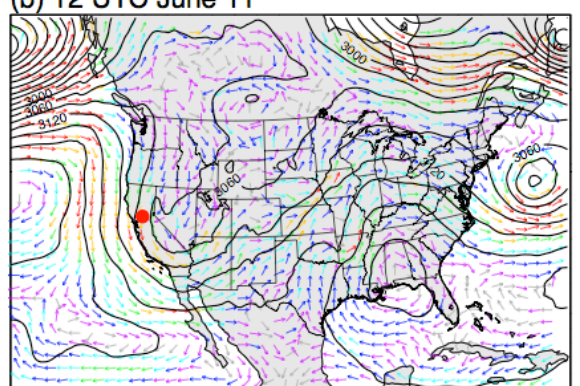

(d) 12 UTC June 16

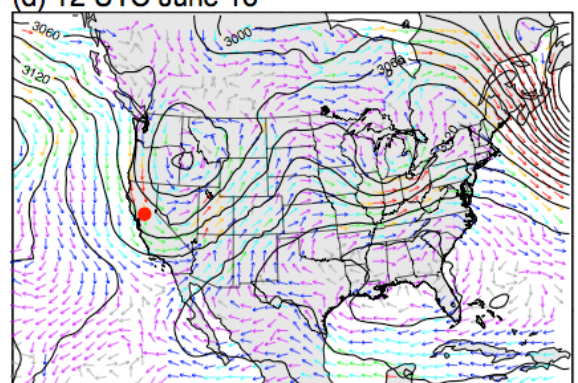

(f) 12 UTC June 27

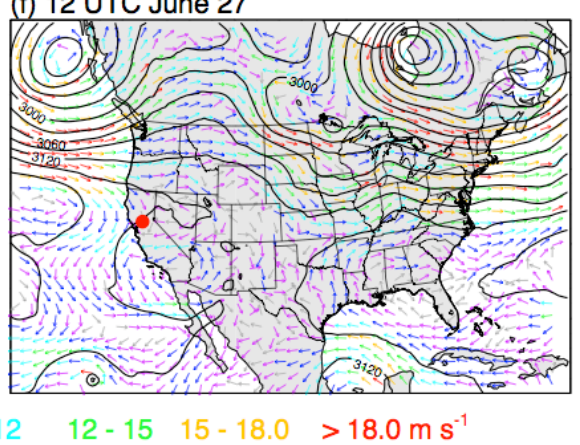

Fig. 3. Winds (arrows) and geopotential heights (contours) at $700 \mathrm{hPa}$ from the NAM analyses at 12:00 UTC on (a) 6 June, (b) 11 June, (c) 14 June, (d) 16 June, (e) 18 June, and (f) 27 June. Red dot denotes Sacramento. Contour interval of $30 \mathrm{~m}$.

conducted in California called CalNex (Cooper et al., 2011; http://www.esrl.noaa.gov/csd/calnex/). The horizontal grid spacings for RAQMS and the parallel NAM-CMAQ simulations were 2 degrees and $12 \mathrm{~km}$, respectively. NAM-CMAQ was run using the 2005 National Emissions Inventory projected for 2008. Background CO mixing ratios derived from the differences between the two NAM-CMAQ simulations over the period ranged from 67 to $116 \mathrm{ppb}$.

During the campaign, the forecasts were used to predict tracer transport so that the principal investigators could plan flight paths up to two days in advance. Particular attention was paid to whether Sacramento sources of $\mathrm{CO}$ would be transported towards the $\mathrm{T} 1$ site and the predicted relative contribution of local sources and San Francisco Bay Area emissions in the region. Animation of the daily forecast products and a map depicting the spatial distribution of the tracer sources is given at http://acrf-campaign.arm.gov/cares/ forecast.
As will be shown later, the performance of the forecast system was successful because the location and relative magnitude of simulated tracer plumes were consistent with $\mathrm{CO}$ measured by the G-1 aircraft. This study evaluates the performance of the modeling system using the field data to support the model's use in helping to explain how meteorological processes contribute to the regional distribution of trace gases and aerosols. Since CO was tagged by source, we provide estimates of which sources likely affected the T0 and $\mathrm{T} 1$ sites as well as how the contribution of those sources vary along the aircraft tracks.

\section{Meteorological conditions}

An overview of the thermally-induced flows influenced by topography in California is given by Bao et al. (2008). For the Sacramento Valley, these include the diurnal upslope and downslope flows along the Sierra and coastal range, 


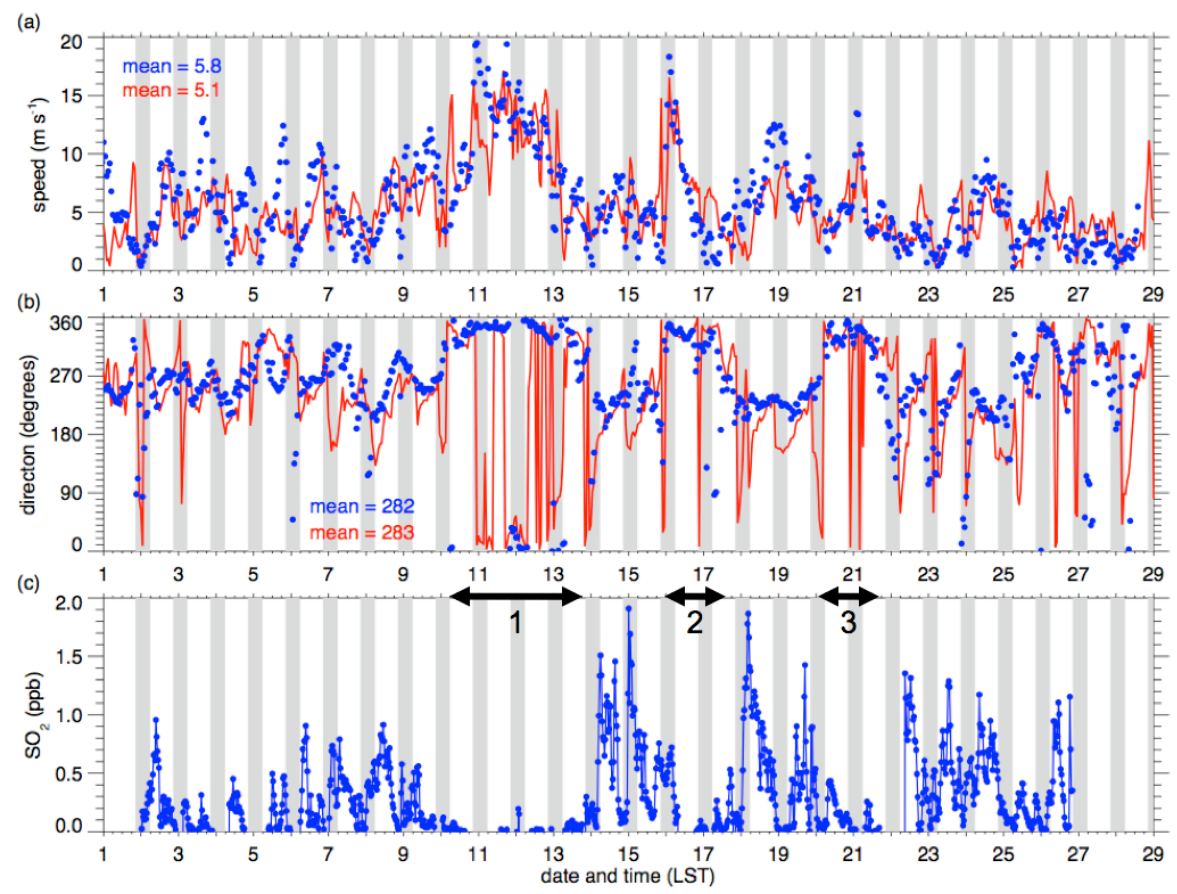

Fig. 4. Observed (a) wind speed and (b) direction at the $563 \mathrm{~m}$ a.g.l. range gate from the Sacramento radar wind profiler (blue dots) along with the simulated winds from the operational WRF forecasts at the same level (red lines). Observed (c) $\mathrm{SO}_{2}$ measured at the T0 site. Gray shading denotes nighttime periods and arrows denote three periods of northwesterly synoptic flow associated with the passage of troughs over California.

the near-surface flow of marine air through the Carquinez Strait (Fig. 1), and the nocturnal Schultz Eddy in the Sacramento Valley. All of these flows were observed during CARES; however, multi-day variations in the synoptic conditions modulated the local flows and influenced the transport and mixing of pollutants in the region.

\subsection{Synoptic-scale winds aloft}

Cool and wet conditions were frequently observed over northern California during May 2010 due to lingering effects of a moderate $\mathrm{El} \mathrm{Nino,} \mathrm{and} \mathrm{intermittent} \mathrm{cloudiness} \mathrm{persisted}$ the first several days of June. While local thermally-driven circulations control the near-surface transport of pollutants, they are modulated by synoptic-scale motions aloft. The 700hPa wind and geopotential height fields at select times during CARES are shown in Fig. 3 to illustrate the evolving synoptic conditions. For comparison, the height of the Sierra Nevada ridgeline reaches its maximum at Mt. Whitney with an elevation of $4.4 \mathrm{~km}$, but is lower in the Lake Tahoe area east of Sacramento where peaks reach around $3 \mathrm{~km}$ elevation.

During the first part of the campaign between 3 and 9 June, winds aloft over central California were generally westerly to southwesterly. This occurred as a result of a low-pressure system over the Gulf of Alaska and a high-pressure system over the southwestern US Relatively strong wind speeds occurred over northern California during this period, with weaker winds over southern California (Fig. 3a). A trough formed over the western US on 10 June, producing strong northerly winds over California by 11 June (Fig. 3b). This trough persisted over the region and gradually weakened by 14 June. While winds aloft on 14 June were still northwesterly, they were much weaker (Fig. 3c). Another trough passed over California two days later on 16 June (Fig. 3d). Westerly winds occurred over northern California by 18 June (Fig. 3e) after this trough rapidly passed over the western US and propagated over southern Canada. A third trough passed over California on 21 June (not shown) that produced northerly winds aloft over northern California; however, this trough was the weakest of the three during the month, with the weakest pressure gradient and wind speeds aloft. After 22 June for the remainder of the month, the upper-level pressure gradients over California were weak, producing light and variable winds at the $700-\mathrm{hPa}$ level such as shown on 27 June (Fig. 3f).

\subsection{Local winds}

The impact of the troughs in the vicinity of Sacramento can be seen in the time series of wind speed and direction at the 563-m level range gate of the profiler, which are shown in Fig. $4 \mathrm{a}$ and $\mathrm{b}$, respectively. Prior to the first major trough, 


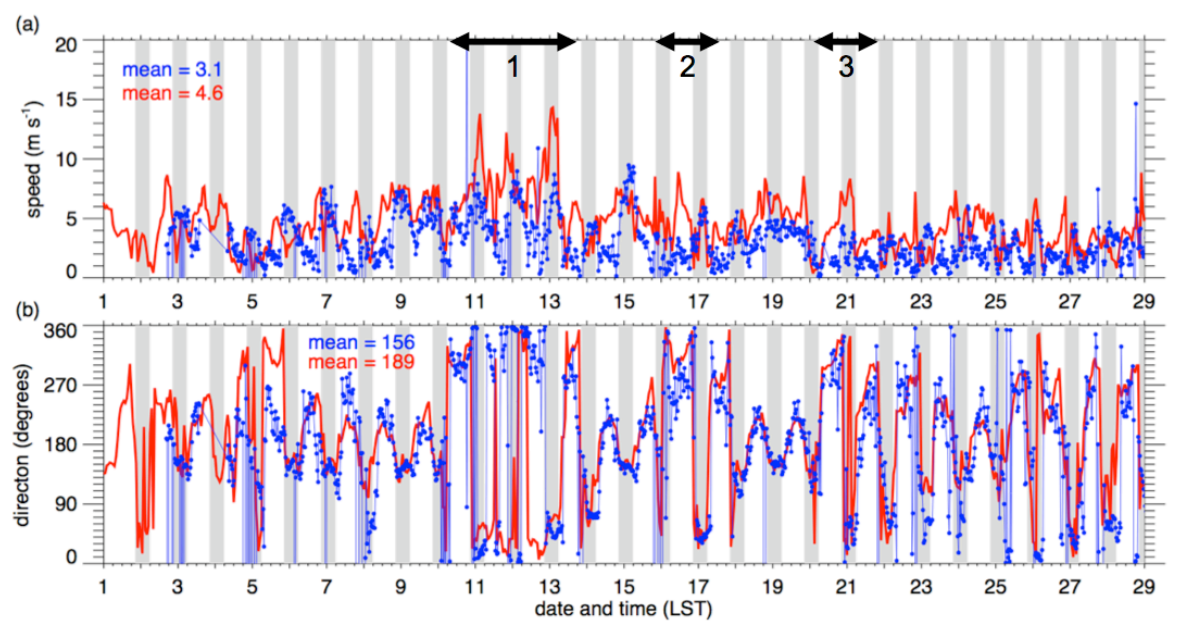

Fig. 5. Observed (a) wind speed and (b) direction at the $100 \mathrm{~m}$ a.g.l. range gate from the T1 sodar (blue dots) along with the simulated winds from the operational WRF forecasts at the same level (red lines). Gray shading denotes nighttime periods and arrows denote three periods of northwesterly synoptic flow associated with the passage of troughs over California.

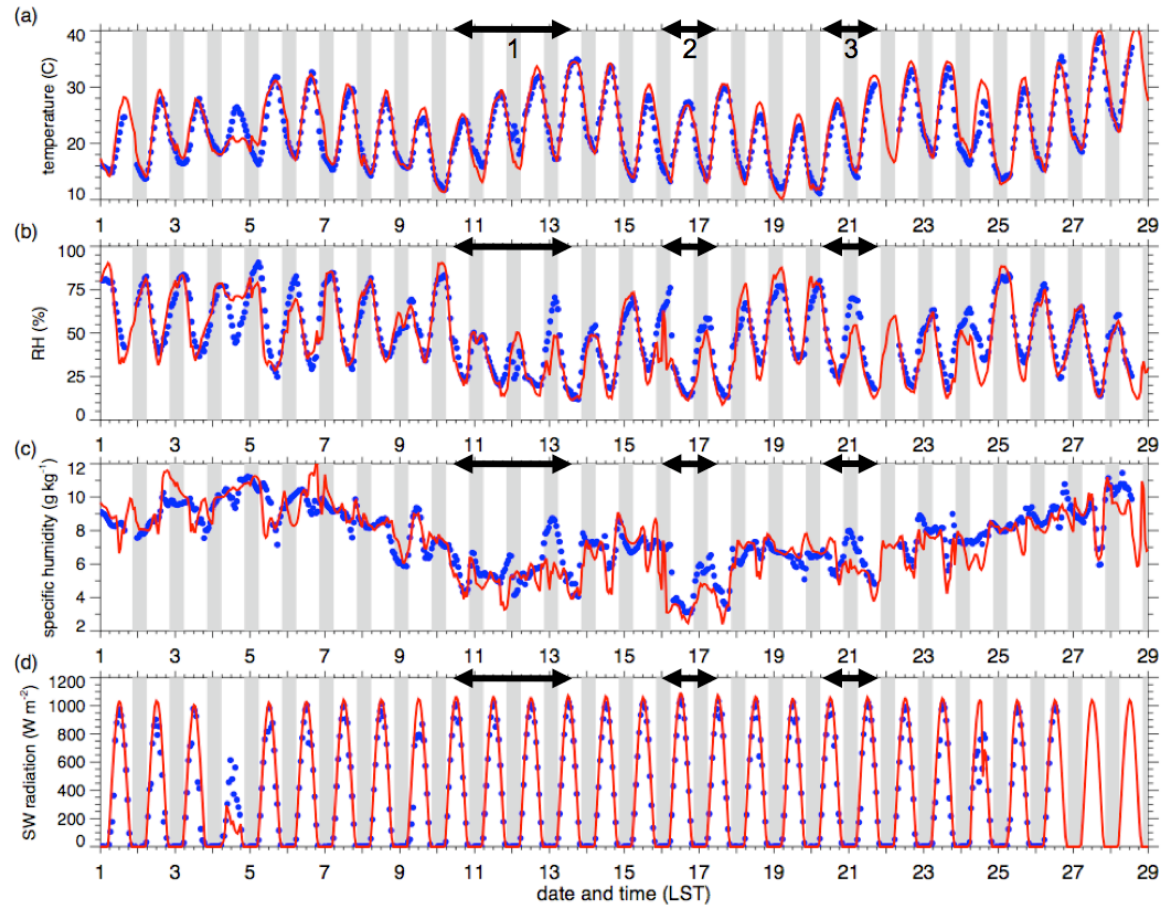

Fig. 6. Observed (blue dots) and simulated (red lines) evolution of (a) 2-m temperature, (b) 2-m relative humidity, (c) 2-m specific humidity, and (d) downward shortwave radiation at the T0 site. Gray shading denotes nighttime periods and arrows denote three periods of northwesterly synoptic flow.

the winds were generally westerly to southwesterly and usually less than $10 \mathrm{~m} \mathrm{~s}^{-1}$. As the first major trough moved through the region on 10 June, the wind direction shifted to the northwest and the speeds increased to as much as $20 \mathrm{~m} \mathrm{~s}^{-1}$. The northwest winds persisted until 14 June when the winds became southwesterly again. The passage of the second and third troughs shifted the winds to the northwest, but the wind speeds were weaker and the duration of the northwesterly winds was much shorter than the first trough. The WRF model was able to simulate much of the temporal wind speed and direction variability at this location. The mean observed and simulated wind speed was 5.8 and 
$5.1 \mathrm{~m} \mathrm{~s}^{-1}$, respectively, and the simulated mean wind direction was nearly the same as observed. The temporal variability of the wind speed and direction at higher altitudes of the radar wind profiler was similar to the 563-m range gate, except that the wind speeds further aloft were weaker. Peak winds speeds during the passage of the troughs occurred between 250 and $600 \mathrm{~m}$ a.g.l.

The impact of the local winds can be seen on $\mathrm{SO}_{2}$ mixing ratios measured at the T0 site, as shown in Fig. 4c. Since there are relatively few large sources of $\mathrm{SO}_{2}$ in the vicinity of Sacramento, the source of observed $\mathrm{SO}_{2}$ was likely the refineries located along the Carquinez Strait (Fig. 1), near the eastern end of San Francisco Bay. The daily westerly flow of marine air usually transported $\mathrm{SO}_{2}$ into the Central Valley and over the $\mathrm{T} 0$ site. The low $\mathrm{SO}_{2}$ mixing ratios during the three troughs indicate that the northwesterly winds transported cleaner air from the northern Sacramento Valley over Sacramento.

The wind speed and direction from the 100-m range gate of the sodar at the T1 site are shown in Fig. 5. This range gate was chosen because it is roughly at the same altitude above sea level as the winds shown in Fig. 4 over the center of the valley. While this range gate is much closer to the ground than the range gate shown for the Sacramento profiler, the wind speeds at the same height above the ground at T0 were usually $5 \mathrm{~m} \mathrm{~s}^{-1}$ higher than at T1 between 11 and 12 June (not shown) during the passage of the first trough. The wind directions associated with the troughs were similar to those at the Sacramento profiler, except that they were somewhat more westerly during daytime. This suggests that the Sierra Nevada still exerted a thermal influence on the nearsurface winds, so that the flow turned up the terrain as the troughs moved through the region. The wind direction at the $\mathrm{T} 1$ site also exhibited much more diurnal variability than over the valley floor. Winds were generally southwesterly during the day. Nocturnal downslope flows were southeasterly (local slope flows) up to 20 June, but after the passage of the third trough the nocturnal downslope flows were northeasterly (predominantly down-valley, following the American River). After the third trough, the diurnal variability in wind direction increased. The WRF model was able to reproduce much of the temporal variability of winds observed during the campaign at both the T0 and T1 sites; however, the simulated wind speed was usually higher than observed in the model grid cell corresponding to the $100-\mathrm{m}$ sodar range gate at $\mathrm{T} 1$. The mean observed and simulated wind speeds at this altitude at the $\mathrm{T} 1$ site were 3.0 and $4.6 \mathrm{~m}^{-1}$, respectively.

\subsection{Local temperature, humidity, and clouds}

Figure 6 shows the diurnal variations in near surface temperature, relative humidity, specific humidity, and solar radiation at the T0 site during the campaign. The temperature variations (Fig. 6a) indicate that the troughs were preceded by a few days of decreasing maximum afternoon temperatures. After the troughs passed over central California, maximum temperatures began to rise again. After the third trough, temperatures increased over the next several days with afternoon peak values reaching $40^{\circ} \mathrm{C}$ on 27 and 28 June. Simulated WRF temperatures agreed with the observations, with a bias of $0.9^{\circ} \mathrm{C}$ and a correlation coefficient of 0.92 .

The time series of relative humidity (Fig. 6b) clearly show increasing values during the afternoon resulting from nearsurface marine air intrusion from the San Francisco Bay Area and peak values at night associated with lower temperatures. But there is also a multi-day variation in relative humidity with the lowest values during the campaign being associated with the passage of troughs and the strong northerly flow that cuts off the marine air intrusions. After a trough passes over the region, descending air aloft adiabatically warms and becomes drier. Consequently, relative humidity during trough events is much lower. Daytime values of relative humidity were generally less than $50 \%$ throughout the campaign, suggesting that uptake of water onto aerosols was likely very small. While relative humidity is often higher near the top of the convective boundary layer, radiosonde measurements often indicated the entire boundary layer was relatively dry as will be shown later. The model was able to reasonably reproduce the variability in relative humidity, which is important for accurately simulating aerosol evolution and aerosol optical properties. The relative humidity mean bias and correlation coefficient over the campaign were $-2.8 \%$ and 0.86 , respectively. Multi-day trends in near-surface moisture are more clearly seen in the time series of specific humidity shown in Fig. 6c. Observed and simulated specific humidity of $10-12 \mathrm{~g} \mathrm{~kg}^{-1}$ occurred between 2 and 7 June, and it decreased during the middle of the month before rising again after the passage of the third trough on 22 June. The lowest values of $3-4 \mathrm{~g} \mathrm{~kg}^{-1}$ occurred during the second trough on 16 June.

Table 3 summarizes the performance of the model in simulating meteorological quantities aloft compared with all of the G-1 flights. While the biases were relatively low for all quantities, simulated temperature and humidity were more highly correlated with observations than wind speed and direction.

The time series of solar radiation shown in Fig. 6d indicates that the field campaign period had mostly sunny skies in the vicinity of Sacramento, but there were many days with cirrus clouds aloft that reduced the peak incoming solar radiation somewhat. 4 and 24 June were the only days in which clouds significantly reduced incoming solar radiation at the surface. WRF overestimated the cloudiness on 4 June, but underestimated cloudiness on 24 June, which likely contributed to the daytime temperature biases (Fig. 6a) on those days.

The overall meteorological conditions during the campaign affected variations in ozone at the $\mathrm{T} 0$ site and at the CARB air quality monitoring station at Cool (Fig. 7). Prior 


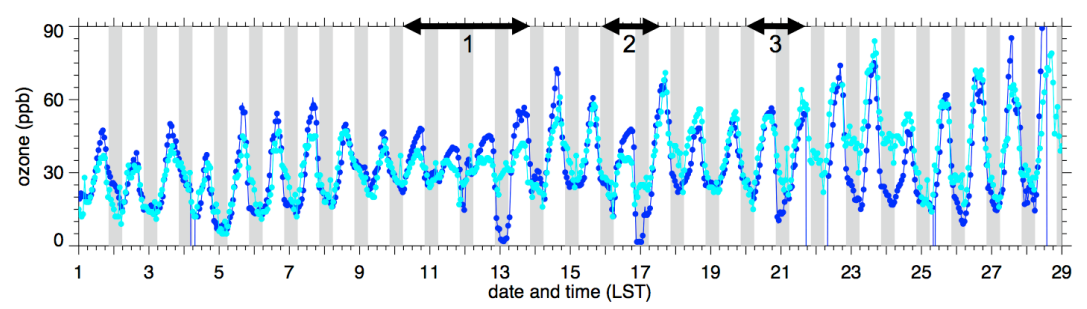

Fig. 7. Observed ozone at the T0 site (dark blue) and from the CARB observations at Cool (light blue). Gray shading denotes nighttime periods and arrows denote three periods of northwesterly synoptic flow.

Table 3. Statistics quantifying the performance of predicted meteorological variables and carbon monoxide along the 21 G- 1 aircraft flights during CARES, where IA is the Index of Agreement that varies between 0 (no agreement) and 1 (perfect agreement).

\begin{tabular}{|c|c|c|c|c|c|c|c|}
\hline Variable & WRF mean & Obs mean & WRF $\sigma$ & Obs $\sigma$ & mean bias & IA & $\begin{array}{l}\text { correlation } \\
\text { coefficient }\end{array}$ \\
\hline Temperature $(\mathrm{K})$ & 295.6 & 295.4 & 5.8 & 5.8 & 0.2 & 0.97 & 0.95 \\
\hline Potential temperature $(\mathrm{K})$ & 301.8 & 301.6 & 4.8 & 5.1 & 0.2 & 0.96 & 0.93 \\
\hline Relative humidity (\%) & 37.3 & 38.5 & 16.0 & 13.7 & -1.2 & 0.86 & 0.75 \\
\hline Mixing ratio $\left(\mathrm{g} \mathrm{kg}^{-1}\right)$ & 6.5 & 6.8 & 2.4 & 2.4 & -0.3 & 0.91 & 0.84 \\
\hline Wind speed $\left(\mathrm{m} \mathrm{s}^{-1}\right)$ & 5.4 & 5.8 & 2.8 & 8.6 & -0.4 & 0.27 & 0.20 \\
\hline Wind direction (deg) & 235.3 & 220.3 & 66.2 & 80.0 & 15.0 & 0.66 & 0.40 \\
\hline Carbon monoxide (ppb) & 137.4 & 150.6 & 47.6 & 197.3 & -13.2 & 0.16 & 0.10 \\
\hline
\end{tabular}

to the first trough, ozone mixing ratios measured at the $\mathrm{T} 0$ site never exceeded $60 \mathrm{ppb}$. The peak afternoon values at Cool were lower than at the T0 site, but the nighttime values were nearly the same. The first trough decreased the diurnal variability of ozone at both sites. Peak afternoon ozone mixing ratios were somewhat higher a few days after this event, before decreasing again during the passage of the second trough. After the third trough, ozone gradually increased during the last part of the campaign, reaching nearly $90 \mathrm{ppb}$ on 27 and 28 June at the T0 site. These two days were also the warmest days of the campaign. Larger differences in ozone between the two sites are also seen throughout the diurnal cycle after 22 June. Peak afternoon values were higher at Cool than at T0 on some days, and the nighttime values at Cool usually became higher than at T0. Differences in ozone between the two sites are likely due to higher titration by NO at night over the city, additional daytime photochemcial production downwind of Sacramento, and local wind patterns that may or may not transport the highest ozone mixing ratios directly over the $\mathrm{T} 1$ site.

\subsection{Boundary-layer depth}

The depth of the boundary layer affects the dilution of trace gases and aerosols via vertical mixing processes, and consequently chemical reaction rates and mixing ratios. Therefore, assessing the performance of simulated boundary-layer depth is important when evaluating predictions of trace gases and aerosols. An example of the observed and simulated po- tential temperature ( $\theta$ profiles along with the boundary-layer depth on 28 June is shown in Fig. 8. In both the model and observations, the estimated boundary-layer depth is based on the gradients of $\theta$ and humidity.

For 28 June, the simulated boundary layer depth is somewhat shallower than observed at 06:00 and 09:00 LST (Fig. $8 \mathrm{a}$ and $\mathrm{b})$. At the T0 site, the near-surface simulated potential temperature is $2-3 \mathrm{~K}$ colder than observed. By 13:00 LST (Fig. 8c), the simulated temperatures become 1 to $2 \mathrm{~K}$ warmer than observed in the boundary layer, which consequently leads to simulated relative humidity being 5$10 \%$ too low. Simulated boundary layer depth at this time is $\sim 0.5 \mathrm{~km}$ higher than observed at T0 and $\sim 0.7 \mathrm{~km}$ higher than observed at T1. Later in the afternoon at 16:00 LST (Fig. 8d), differences between the simulated and observed boundary layer depth decrease to $\sim 0.2 \mathrm{~km}$ at the T1 site. Errors in the evolution of the simulated boundary layer depth on this day, and on many other days, are associated with timing. Such differences could affect the interpretation of comparisons of observed aircraft trace gases and simulated quantities aloft, as will be shown later.

The overall performance of the WRF model in simulating boundary-layer depth during the campaign is shown in Fig. 9. The simulated boundary-layer depths were usually within $30 \%$ of the observed depths. Averaged over the entire campaign, WRF-predicted boundary-layer depths were 5-10\% higher than observed at all times of the day. The biases at the T0 and T1 sites at 16 LST were 44 and $188 \mathrm{~m}$, respectively, 

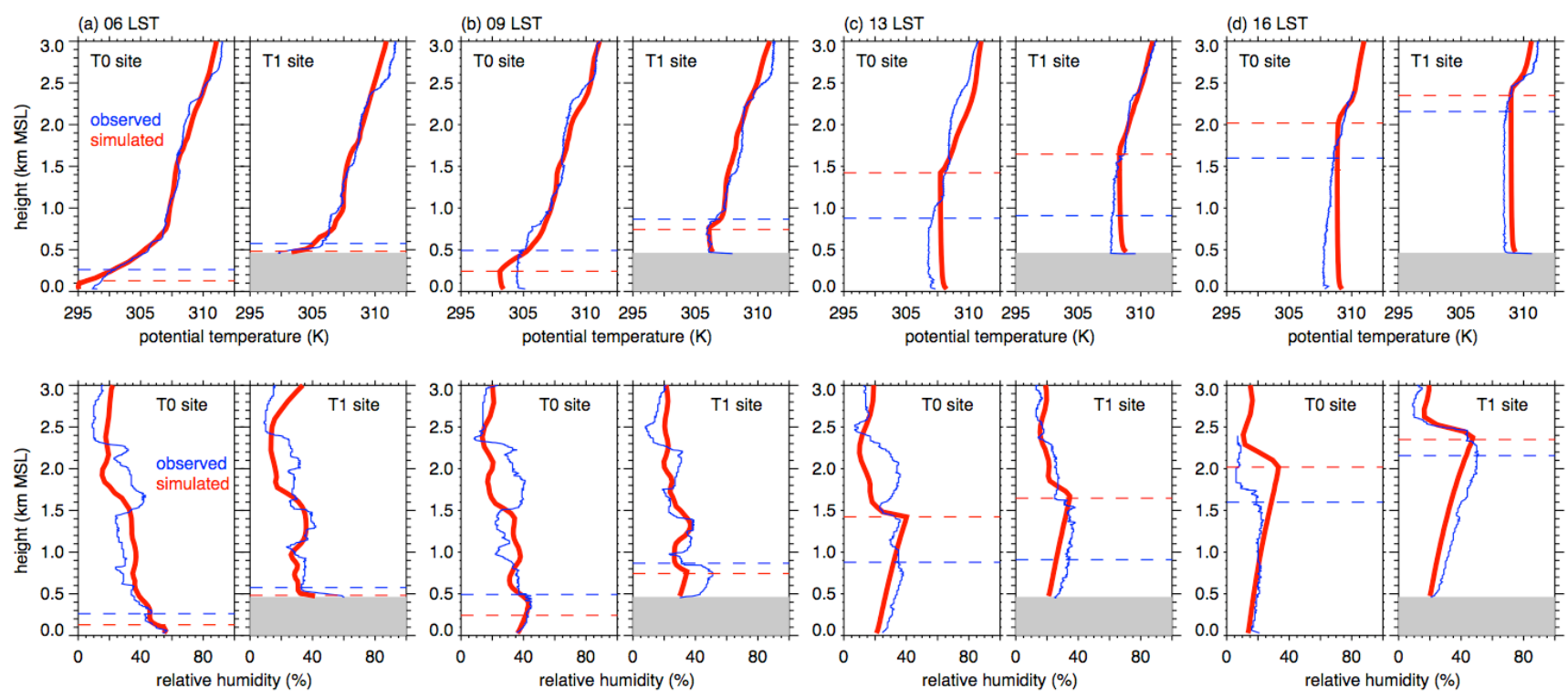

Fig. 8. Observed (blue) and simulated (red) potential temperature and relative humidity profiles (solid lines) and boundary layer depths (dashed lines) at the surface sites on 28 June 2010. Radiosonde at 11:00 LST was not launched on this day. Gray shading denotes terrain height at the $\mathrm{T} 1$ site.

(a) Boundary-layer depth at T0 site

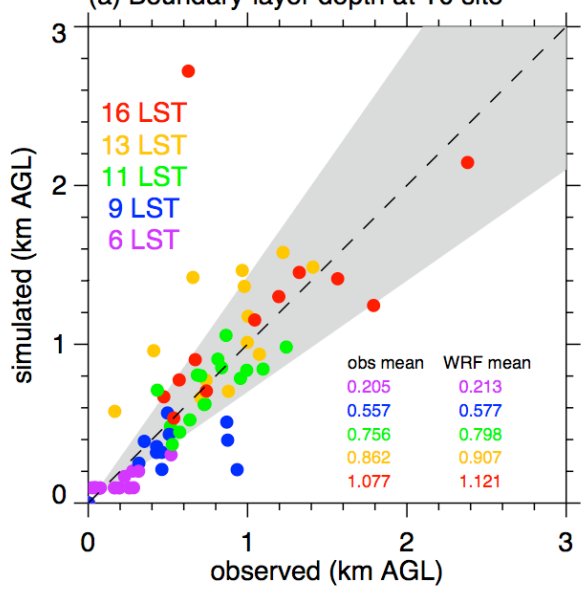

(b) Boundary-layer depth at T1 site

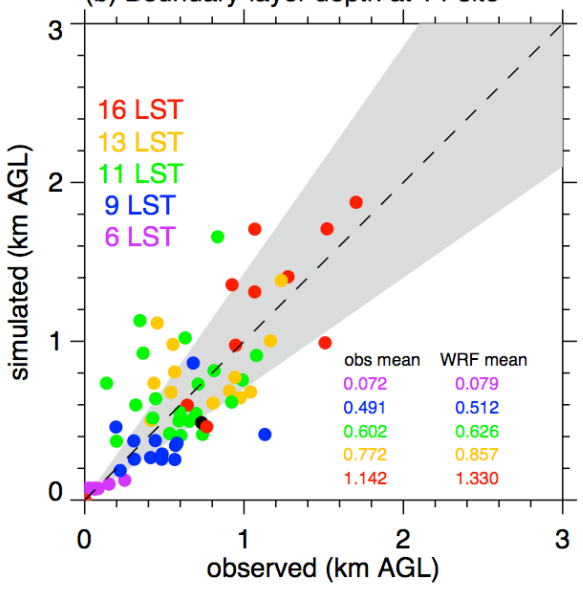

Fig. 9. Observed and simulated convective boundary layer (CBL) depths at various times of day at the (a) $\mathrm{T} 0$ and (b) $\mathrm{T} 1 \mathrm{sites}$. Observed values were obtained from radiosondes launched up to 5 times per day. Dashed line denotes 1:1 line while gray shading denotes $\pm 30 \%$ range.

suggesting that model performance was somewhat worse over the higher terrain.

Boundary-layer depths can also be estimated from aerosol profiles obtained from lidars (e.g. Shaw et al., 2007; Van Pul et al., 1994). Airborne lidars provide an opportunity to quantify spatial and temporal variations in boundary layer depth (e.g. White et al., 1999) that are difficult to obtain by other methods that rely on fixed sites. An automated wavelet technique adapted from the one described by Brooks (2003) has been applied to the HSRL data. This technique determines the top of the boundary layer by finding the peak vertical gradient in the aerosol backscatter. Because there are often layers of aerosols above the boundary layer, the technique attempts to differentiate between the boundary-layer top and other peaks in the vertical gradient in aerosol backscatter. Conversely, the WRF-simulated boundary-layer top is determined where the vertical gradient in potential temperature exceeds a threshold.

A comparison of the HSRL and simulated boundary-layer depths during the day over the entire campaign is shown in 


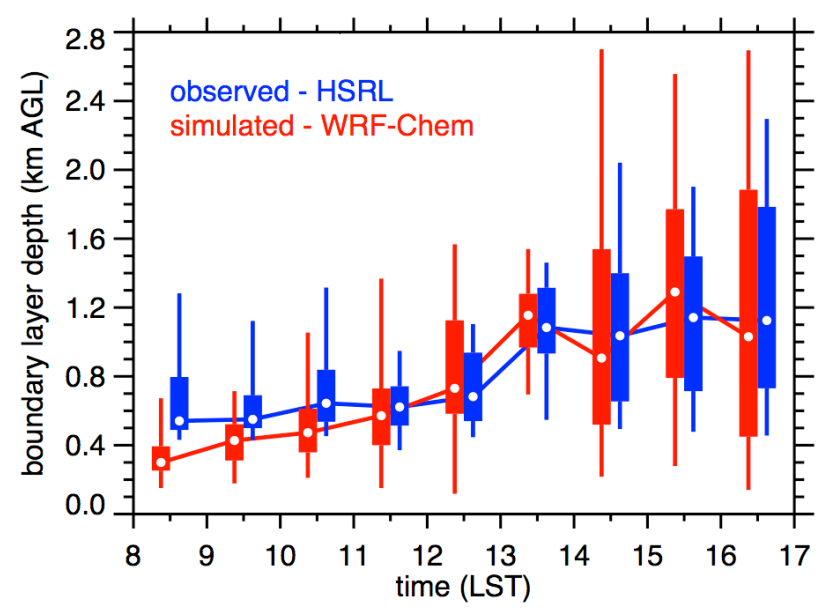

Fig. 10. Observed (blue) and simulated (red) boundary layer depth along the B-200 flight paths over central California in terms of percentiles for each hour of the day over the entire campaign. Filled boxes denote the 25 th and 75 th percentiles and vertical lines denote the 5 th and 95 th percentiles. Lines connecting the white dots denote the median value for each hour.

Fig. 10, expressed in terms of percentiles. Differences in the techniques (aerosol gradients versus potential temperature gradients) contribute to uncertainties in the boundarylayer height estimates. Nevertheless, the two methods produce qualitatively similar results, with low boundary-layer depths during the morning and higher depths with increased variability during the afternoon. Depths derived from WRF are usually lower than those from HSRL before 11:00 LST, but the median and range of the 25th and 75th percentiles are similar after 11:00 LST. The large spatial variability in boundary-layer depth over central California along the B-200 flight paths between the two methods was often very similar as well (not shown).

Despite the differences between the two methods of estimating boundary-layer depth, estimates derived from HSRL will be extremely useful since it provides spatial and temporal evolution of the boundary layer that cannot be obtained from any other type of information and therefore can more rigorously evaluate meteorological models, such as WRF. A more in-depth analysis of boundary-layer depths derived from HSRL data compared with WRF simulations will be presented in future studies.

\section{Anthropogenic influences in the vicinity of Sacramento}

Since the meteorological quantities predicted by WRF are often similar to the observations during CARES, the model is expected to adequately represent the transport and mixing of the $\mathrm{CO}$ tracers emitted from anthropogenic sources. We now evaluate how well the predicted spatial and temporal variabil- ity in CO compares with measurements collected both on the G-1 aircraft and at the two surface sites. The relative contribution of various source regions at the sampling locations predicted by the model is also quantified. We first examine the spatial distribution of $\mathrm{CO}$ along the G-1 flight paths on 28 and 21 June when the daytime winds in the boundary layer were southwesterly and northwesterly, respectively.

\subsection{CO tracers aloft}

During the morning of 28 June, the highest $\mathrm{CO}$ mixing ratios were observed close to the emission sources in Sacramento (Fig. 11a). CO mixing ratios often exceeded $250 \mathrm{ppb}$ over the city, while lower CO mixing ratios between 140 and $200 \mathrm{ppb}$ were measured along the flight transects over the T1 site. Simulated $\mathrm{CO}$ variations include a background value from the RAQMS/NAM-CMAQ modeling system of $90 \mathrm{ppb}$ on this day and are very similar to measurements over most of the flight path. The largest difference was produced for the profile obtained up to $2.5 \mathrm{~km}$ m.s.l. around 09:00 LST when the simulated CO mixing ratios were just above the $90 \mathrm{ppb}$ background values and observed $\mathrm{CO}$ varied between 120 and $160 \mathrm{ppb}$. The model suggests that 40 to $80 \%$ of the CO over the city originated from the Bay Area. As the convective boundary layer grew, the relative contribution from the Sacramento source increased after 11:00 LST and the contribution from the Bay Area decreased to about $30 \%$. The model also indicates that in the vicinity of T1 during the late morning, CO originated from Sacramento, Sacramento Valley, Bay Area, and local foothills sources with approximately equal contributions.

As the southwesterly upslope flow strengthened during the day, CO emitted from Sacramento was transported over the foothills, with the plume centerline passing south of the T1 site as shown in Fig. 11d for the afternoon G-1 flight. The G-1 aircraft found CO mixing ratios as high as $250 \mathrm{ppb} 12$ to $20 \mathrm{~km}$ southeast of the T1 site. The simulated spatial distribution of $\mathrm{CO}$ is similar to the observations, with peak values occurring within a few kilometers of observed peak values. However, the simulated magnitude is too low compared to the observations. In addition to uncertainties in emission rates, the under-prediction in $\mathrm{CO}$ mixing ratios may be due to two factors. First, the predicted boundary layer depth during the afternoon is too deep over the valley floor as shown in Fig. 8, which would dilute simulated $\mathrm{CO}$ mixing ratios. Second, it is possible that the background concentrations are too low on this day, as indicated by the profile during the morning shown in Fig. 11a. However, the simulated profile of $\mathrm{CO}$ at 14:30 LST is very similar to the measurements. In contrast with the morning, the $\mathrm{CO}$ plumes during the afternoon are comprised primarily of emissions from Sacramento. Between the morning and afternoon G-1 flight, much of the Bay Area CO plume was transported out of the region (not shown) so that the contribution from the Bay Area was usually less than $20 \%$ at the same locations as the Sacramento plume. 
(a) Observed CO Along Morning G-1 Flight on June 28
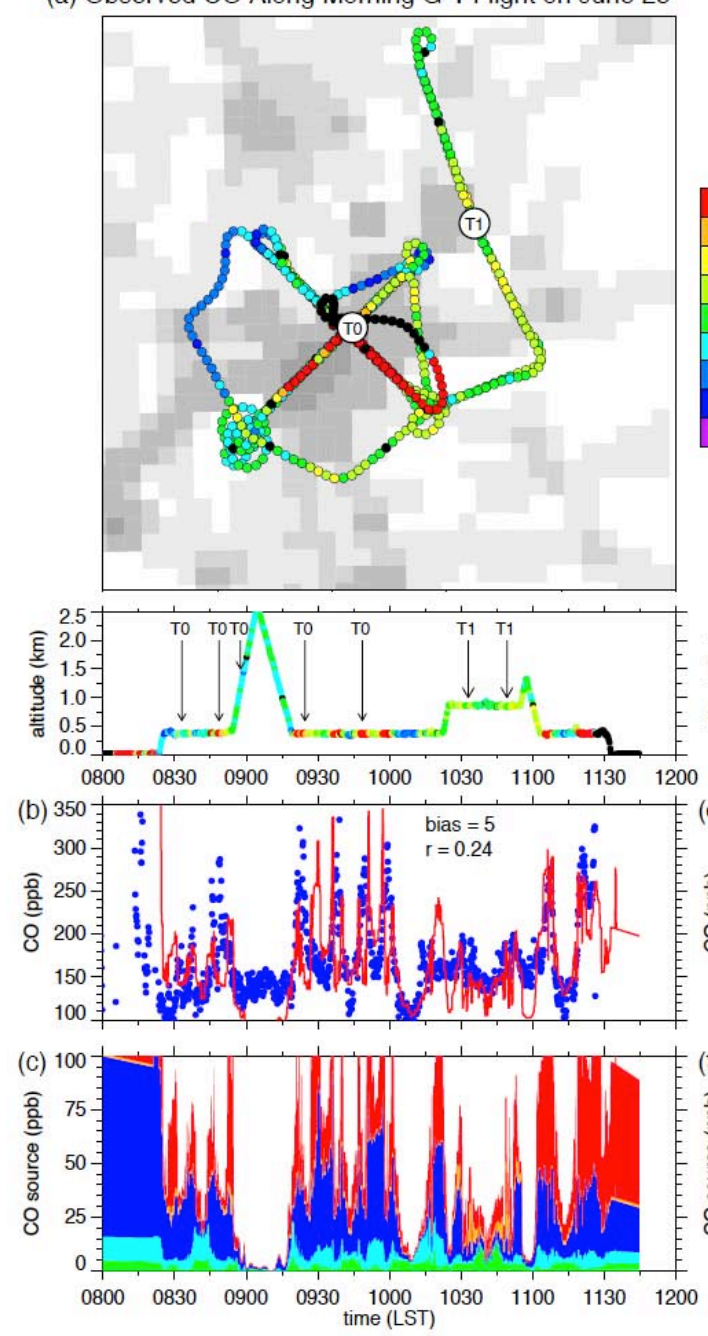

(d) Observed CO Along Afternoon G-1 Flight on June 28
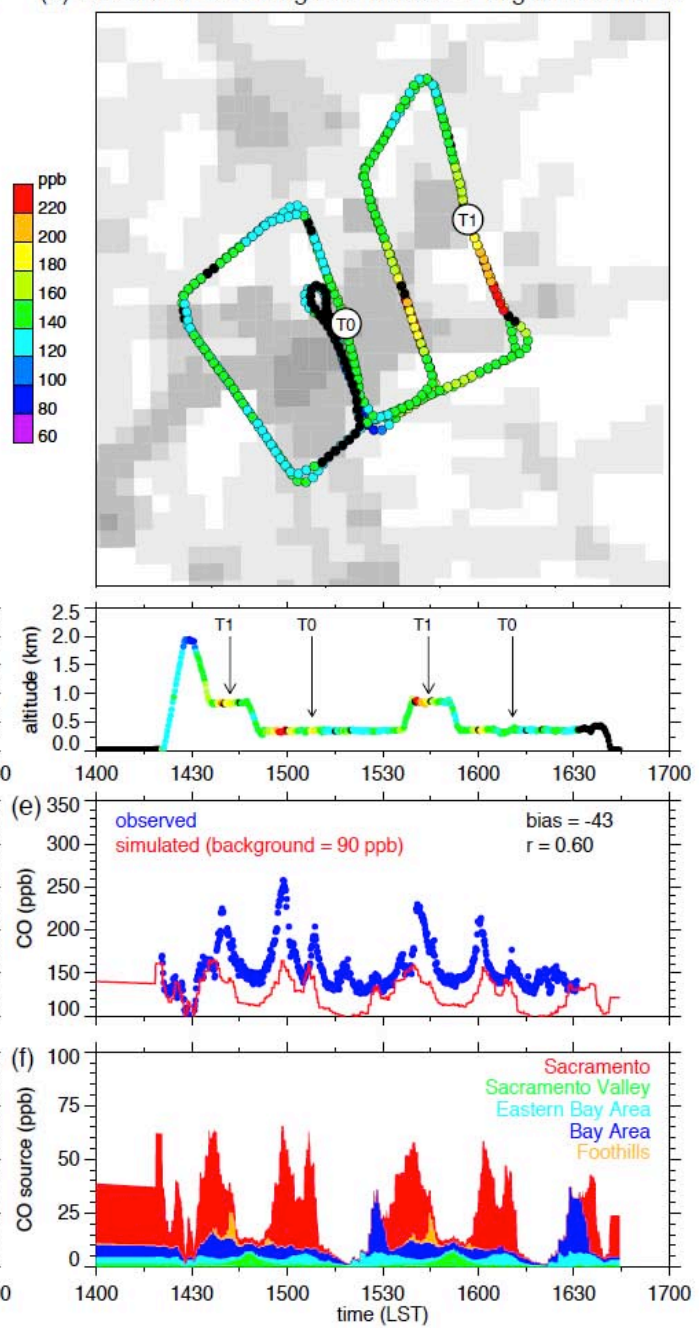

Fig. 11. (a) Spatial distribution of observed CO along the G-1 flight path during the morning of 28 June (b) time series of observed and simulated CO, and (c) simulated CO originating from various source regions. Figures (d), (e), and (f) are the same as (a), (b), and (c), except for the afternoon of 28 June. Gray shading in (a) and (d) denotes emission rate of CO from the CARB inventory reapportioned to the WRF grid and black dots denote missing data.

The southwesterly transport shown in Fig. 11 occurred frequently during CARES, although the position of the plume centerline passed south of $\mathrm{T} 1$, directly over the T1, or north of T1 depending on the exact wind direction on each day. As discussed previously, the passage of upper-level troughs and northwesterly winds over central California disrupted the local valley and upslope flows; therefore, we next examine the distribution of $\mathrm{CO}$ during these meteorological conditions.

As shown in Fig. 12, the G-1 flight plan was modified on 21 June to have two southwest-to-northeast transects perpendicular to the anticipated trace gas and aerosol plume downwind of Sacramento associated with the northwesterly winds. During the morning (Fig. 12a), CO was as high as $210 \mathrm{ppb}$ over the city in the vicinity of the T0 site with lower mixing ratios observed downwind. Peaks in the $\mathrm{CO}$ mixing ratios, denoted by $\mathrm{B}, \mathrm{C}, \mathrm{D}, \mathrm{E}, \mathrm{F}$, and $\mathrm{H}$, indicate locations where the G-1 likely intersected the Sacramento plume. Simulated $\mathrm{CO}$ was qualitatively similar to the observations, except that the simulated $\mathrm{CO}$ over the city was too low and the simulated $\mathrm{CO}$ from $\mathrm{A}$ to $\mathrm{B}$ and from $\mathrm{C}$ to $\mathrm{D}$ was higher than observed. The model indicates the contribution of emission sources outside of Sacramento to $\mathrm{CO}$ in the vicinity of the T0 site was small, with $10 \mathrm{ppb}$ of $\mathrm{CO}$ transported from other sources in the Sacramento Valley. For the transects southeast of Sacramento, the simulated Sacramento tracer contributed to a large fraction of the $\mathrm{CO}$ from $\mathrm{A}$ to $\mathrm{B}, \mathrm{C}$ to $\mathrm{D}$, and $\mathrm{G}$ to $\mathrm{H}$. For segment $C$ to $D$ of Fig. 12a, the aircraft flew from $C$ to the northeast end of the transect, and then back over the same locations towards the southwest to $\mathrm{D}$. The locations of the peak simulated CO therefore occurred northeast of the observed 
(a) Observed CO Along Morning G-1 Flight on June 21
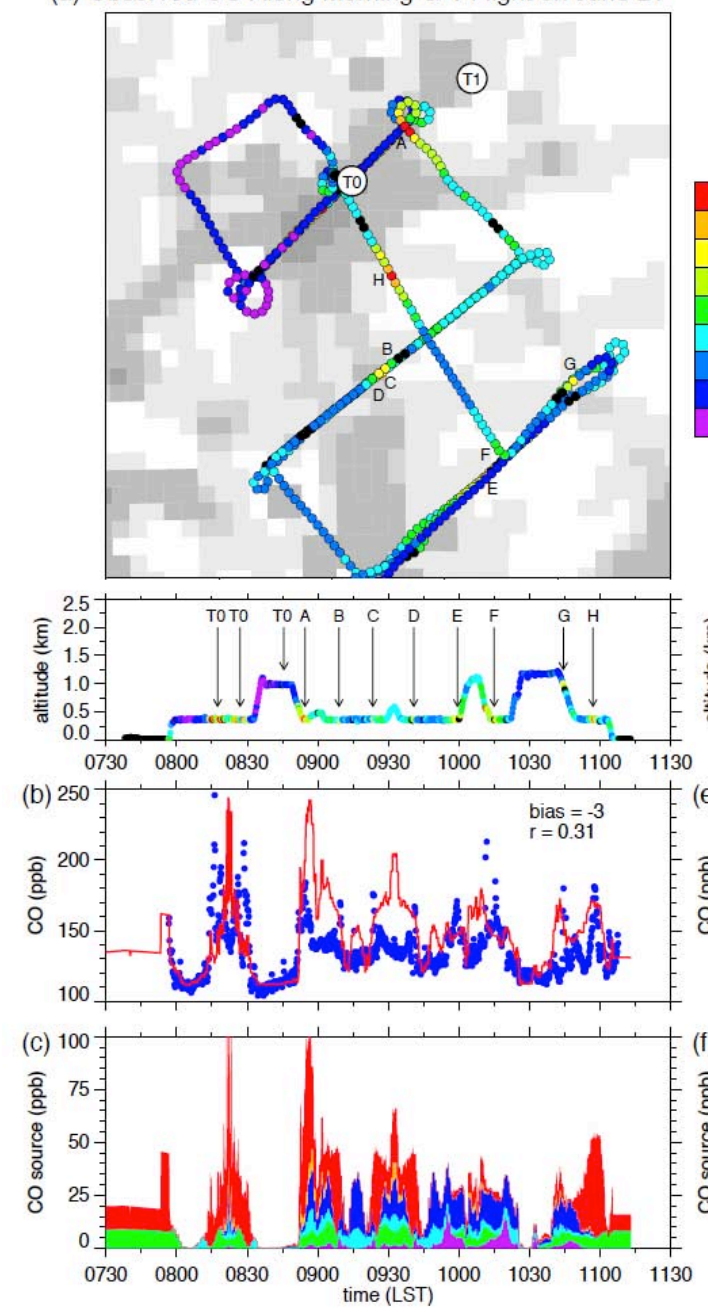

(d) Observed CO Along Afternoon G-1 Flight on June 21
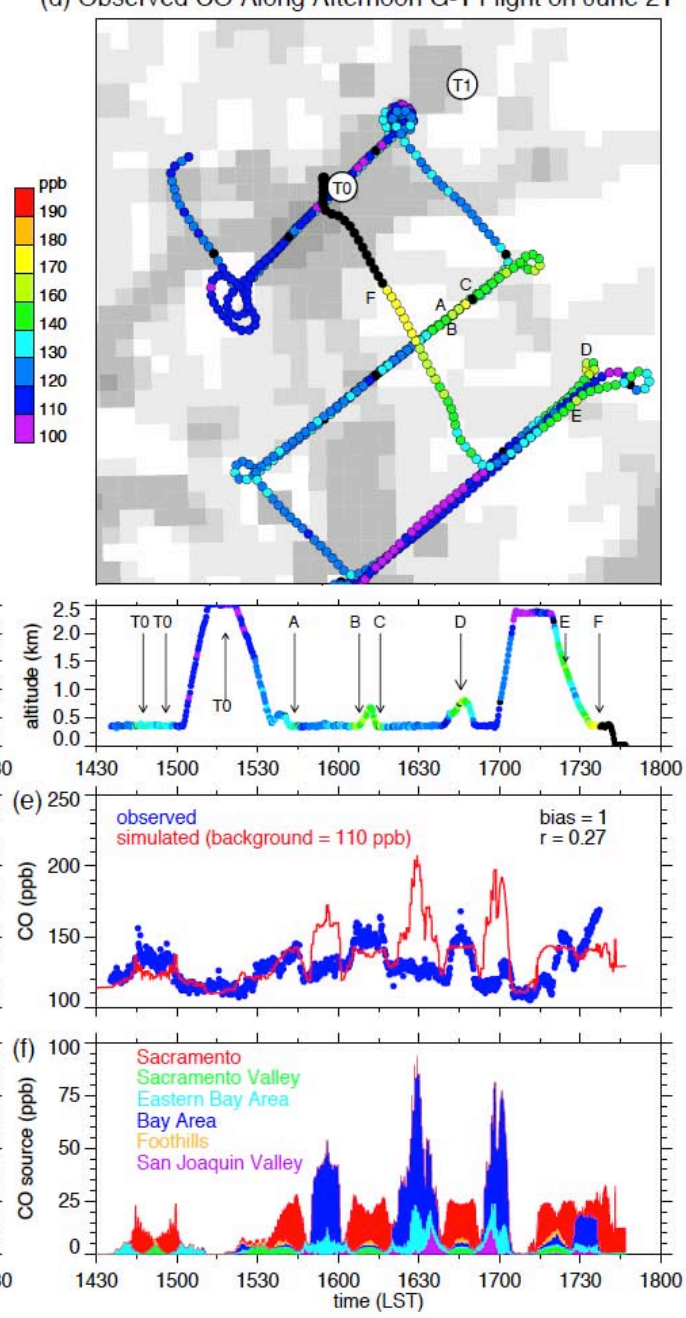

Fig. 12. Same as Fig. 11, except for 21 June.

peak of CO near points $\mathrm{C}$ and $\mathrm{D}$. The aircraft data also indicates an abrupt peak on $\mathrm{CO}$ near points $\mathrm{C}$ and $\mathrm{D}$ whereas the simulated plume width was broader. Bay Area emissions comprised a large fraction of the CO south of Sacramento as the plume from this region was transported through the Carquinez Strait and then into the San Joaquin Valley by the northwesterly winds. San Joaquin emission sources began to contribute to a significant fraction of $\mathrm{CO}$ along the transect farthest from Sacramento.

During midday of 21 June, near-surface wind shifted slightly to the west so that peak downwind $\mathrm{CO}$ mixing ratios during the afternoon were located $\sim 20 \mathrm{~km}$ east of the morning's plume centerline. During the morning the observed plume centerline was located near points $C$ and $D$ in Fig. 12a, but peak $\mathrm{CO}$ mixing ratios during the afternoon were further east as indicated by the location of the yellow and green dots in Fig. 12b. Points A-F in Fig. 12b denote peaks in the $\mathrm{CO}$ mixing ratios that likely originate from Sacramento that are also consistent with the high fraction of simulated Sacramento CO tracer at those locations. In contrast with the morning in which multiple sources are mixed together in the valley atmosphere south of Sacramento, the CO in the valley during the afternoon is divided into two distinct plumes. One plume located over the eastern valley is made up mostly by the downwind Sacramento plume with low concentrations from Sacramento Valley sources. The other plume is located on the west side of the valley and is comprised mostly of Bay Area and San Joaquin Valley sources. Over the western side of the valley, the simulated $\mathrm{CO}$ mixing ratios are too high at 16:00, 16:30, and 17:00 LST suggesting that there are errors associated with transport and mixing of the Bay Area plume on this day. It is possible that the model overestimated the influx of air through the Carquinez Strait, and that in reality those emissions were transported elsewhere.

The model predicted reasonably well the timing and location of the Sacramento CO plume on most days, and the 


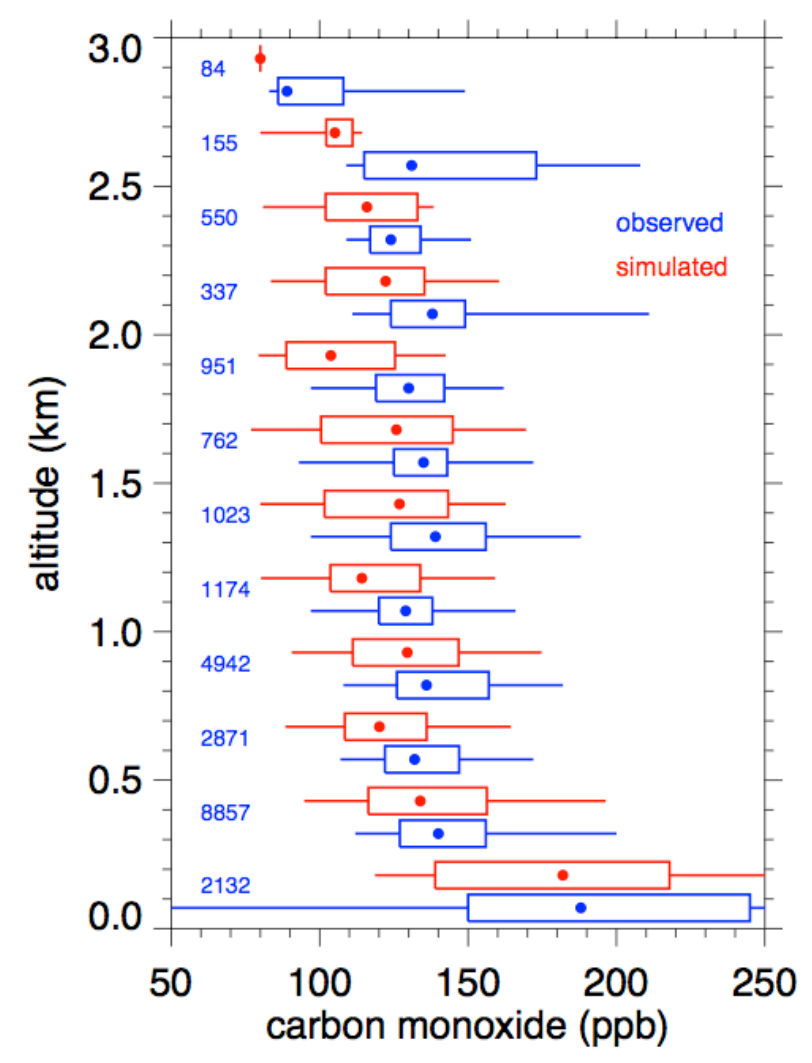

Fig. 13. Observed (blue) and simulated (red) carbon monoxide binned over 250-m increments along all of the G-1 flight paths, expressed in terms of percentiles. Dots denotes 50th percentile, boxes denotes range between 25 th and 75 th percentiles, and lines denote 5 th and 95 th percentiles.

WRF-Chem forecasts were useful to help guide aircraft operations by identifying transport patterns that were consistent with the campaign objectives and determining which flight pattern to perform. The performance of the model in simulating $\mathrm{CO}$ aloft for all G-1 flights is summarized by the statistics listed in Table 3 and percentiles that have been binned into 250-m increments as shown in Fig. 13. Bins with higher number of samples indicate the altitudes at which the aircraft flew most often. Overall, the simulated and observed percentiles are very similar within $0.5 \mathrm{~km}$ of the ground. Above this altitude, simulated median $\mathrm{CO}$ was usually 10 to $20 \mathrm{ppb}$ lower than the measured median. The likely explanations for the under-prediction aloft are the uncertainties in the background concentrations from long-range transport and over-predictions of the afternoon boundary layer height (e.g. Figs. 8 and 9) that excessively dilute simulated CO mixing ratios. The correlation coefficient is only 0.10 because of relatively small displacements in the simulated Sacramento plume when compared to the observed plume.

\subsection{CO tracers at the T0 and T1 sites}

We next describe variations in $\mathrm{CO}$ at the surface at the T0 and $\mathrm{T} 1$ sites during the campaign, since one objective of CARES is to characterize transport between Sacramento and the downwind site that affects the interpretation of aerosol aging derived from the measurements. Evaluating simulated $\mathrm{CO}$ at T0 (Fig. 14) will help determine if the emissions of $\mathrm{CO}$ and the boundary layer processes in Sacramento are simulated adequately. Prior to the campaign we expected that southwesterly winds would transport trace gases and aerosols over the foothills, leading to increases in those quantities during the late afternoon and early evening. Evaluating simulated $\mathrm{CO}$ at T1 (Fig. 15) and quantifying the contributions of the sources regions will help define periods when this transport scenario likely occurred.

Figure 14a shows the 30-min averaged observations of $\mathrm{CO}$ at the $\mathrm{T} 0$ site, along with the simulated $\mathrm{CO}$ from the operational WRF-Chem forecasts, the simulated $\mathrm{CO}$ from the RAQMS/NAM-CMAQ modeling system, and the derived temporal variability of background $\mathrm{CO}$. The simulated multiday and diurnal variations in $\mathrm{CO}$ from the operational WRFChem forecasts are similar to the measurements; however, the correlation coefficient is only 0.38 and the simulated concentrations are too high on most days. The observed and simulated $\mathrm{CO}$ mixing ratios averaged over the month of June are 152 and $230 \mathrm{ppb}$, respectively. The temporal variations in CO predicted by RAQMS/NAM-CMAQ in Sacramento are similar to WRF-Chem, and the correlation coefficient of between RAQMS/NAM-CMAQ and the observations is 0.33 . While the concentrations of CO from RAQMS/NAM-CMAQ are also too high with mean value of $186 \mathrm{ppb}$, they are closer to the observations than those from WRF-Chem. Some differences are expected between the two models because the lateral boundary conditions, grid spacing, choice of meteorological parameterizations, and emissions inventories employed are not the same.

The average diurnal variation of CO, shown in Fig. 14b, more clearly depicts the biases in the two models. If a correction is applied that subtracts the mean bias from the WRFChem predictions, denoted by the dashed line, then the diurnal variation is quite similar to the measurements. Peaks in the observations tended to occur in the morning just after sunrise and just after sunset because traffic emission rates are higher and the boundary layer depths lower during those periods. During the afternoon, the deeper convective boundary layer reduces $\mathrm{CO}$ concentrations. While the WRF-Chem predicts peaks at the correct times and with higher concentrations after sunset than just after sunrise, the peaks from RAQMS/NAM-CMAQ usually occur 2 to $3 \mathrm{~h}$ sooner than observed and there is little distinction between the peak values during the morning and early evening.

The fact that the simulated non-bias-corrected $\mathrm{CO}$ mixing ratios at the T0 site are high relative to observations contrasts with the finding that simulated $\mathrm{CO}$ within $0.5 \mathrm{~km}$ of 

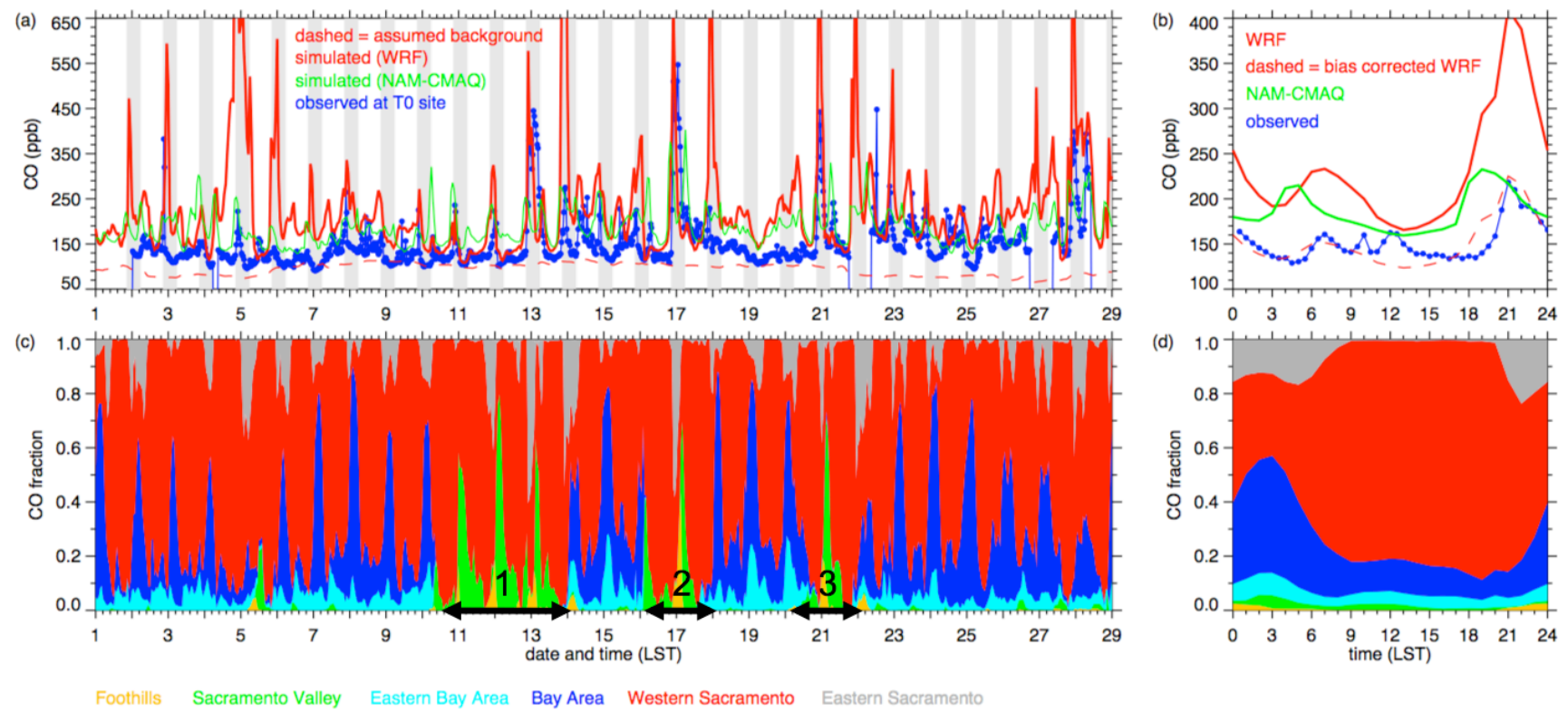

Fig. 14. (a) Observed and simulated $\mathrm{CO}$ at the $\mathrm{T} 0$ site in Sacramento and (b) average diurnal variation in CO during June 2010. In (a) gray shading in denotes nighttime periods and the dashed red line is the derived background CO mixing ratio described in text. (c) Relative contribution of each source region to the simulated $\mathrm{CO}$ mixing ratios at the $\mathrm{T} 0$ site and (d) average diurnal variation of $\mathrm{CO}$ from each source region during June 2010. Arrows denote three periods of northwesterly synoptic flow.
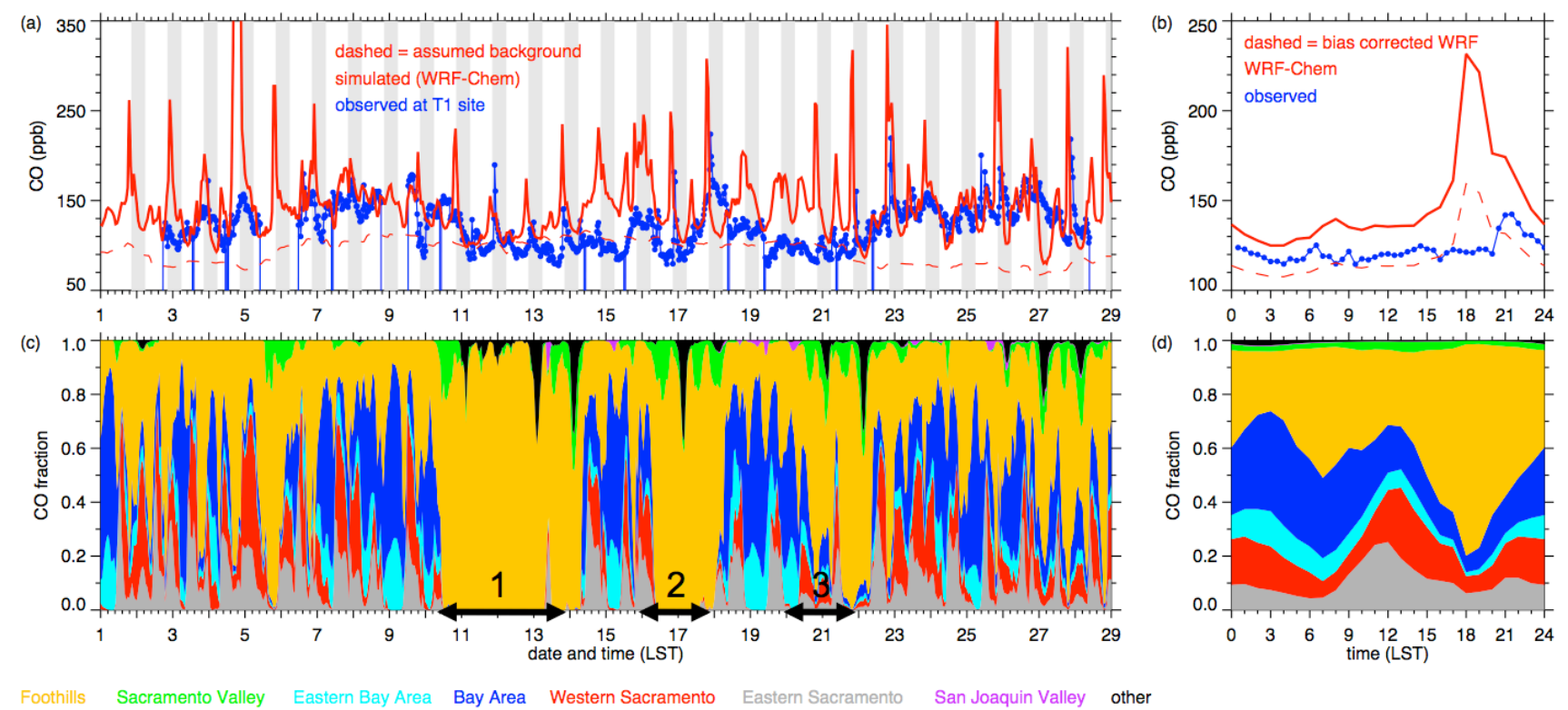

Fig. 15. Same as Fig. 14, except at the T1 site northeast of Sacramento.

the surface throughout the modeling region is similar to the G-1 measurements (Fig. 13). The most likely explanation is the resolution of the emissions inventory that contains fixed emission rates within $4 \times 4 \mathrm{~km}$ grid cells. T0 is located close to Interstate 80 (Fig. 1b) and Auburn and they occupy the same or adjacent grid cells in the model. Thus, within the model high traffic emissions are spread over the T0 site regardless of the wind direction. WRF-Chem could be run with smaller grid spacings to better resolve local traffic emissions, but results would not change significantly unless the resolution of the emissions inventory could be increased as well. Another potential explanation could be that the simulated 
vertical extent of mixing during the early morning and after sunset is too low. Figure 9 shows that the simulated boundary layer depth during the early morning at $\mathrm{T} 0$ was too low on several days; however, there are no measurements to evaluate predicted boundary layer height after sunset. One also could argue that the emission rates may be too high, but decreasing the emission rates by a factor of two would then lead to $\mathrm{CO}$ mixing ratios being too low in comparison with $\mathrm{G}-1$ measurements.

The contributions of $\mathrm{CO}$ from the source regions influencing the T0 site in Fig. 14c show that local Sacramento contributes the largest fraction, as expected. Bay Area emissions are present in Sacramento every day, except for three periods (11-13, 16-17, 21 June) when troughs passed over California and transported CO to the south and east. During the trough events, $\mathrm{CO}$ emissions from sources in the Sacramento Valley are present in Sacramento but the magnitude is relatively low. The model also shows that emissions in the foothills could be transported as far as the T0 site by nighttime downslope winds on some days, but this was not a common occurrence. The Bay Area contribution has a diurnal variation that is similar from day to day, as shown in Fig. 14d, and contributes to a large fraction of the total CO at night. While $\mathrm{CO}$ that is transported from the Bay Area through the Carquinez Strait arrives in Sacramento during the late afternoon and early evening, the relative fraction of $\mathrm{CO}$ from the Bay Area does not increase. At night, additional $\mathrm{CO}$ from the Bay Area is transported into Sacramento as the local emissions are transported over the Sierra, so that the fraction of $\mathrm{CO}$ in Sacramento becomes on average as high as 50\% at 03:00 LST (Fig. 14d). Winds through the Carquinez Strait also diminish at night so that the transport of fresh emissions diminishes until the thermally-driven winds form the next day. The pulse of $\mathrm{CO}$ from the Bay Area is transported north into the Sacramento Valley or south into the San Joaquin Valley before sunrise so that the most of the CO in the early morning originates primarily from Sacramento.

The variation of $\mathrm{CO}$ at the $\mathrm{T} 1$ site in the foothills, as well as the sources that contribute to $\mathrm{CO}$, is significantly different than at T0, as shown in Figure 15. The observations do not show strong peaks during the morning (Fig. 15a) because the site is not located close to large mobile sources as is the $\mathrm{T} 0$ site. There are peaks in $\mathrm{CO}$ during the late afternoon and early evening on some days that are likely associated with transport from Sacramento and other nearby sources to the site. While the model is qualitatively similar to the measurements on many days, there are differences. For example, simulated CO is consistently too high from $14-16$ and $18-$ 20 June and simulated afternoon peak values are higher than observed on many days. The observed and simulated CO mixing ratios averaged over the month of June are 122 and $150 \mathrm{ppb}$, respectively, and the overall correlation coefficient is only 0.15 . For those days in which the temporal variation is similar to observed, the simulated peak values often occur a few hours sooner than observed because the upslope near- surface winds are somewhat higher than observed (Fig. 5a). As with the T0 site, the resolution of the emissions is a likely reason for the over-prediction of $\mathrm{CO}$ around sunset. The local emissions associated with the smaller communities, such as Auburn, Placerville, and the Interstate 80 and Highway 50 corridors may be poorly represented and influence the $\mathrm{T} 1$ site too often.

The observed average $\mathrm{CO}$ at $\mathrm{T} 1$ during the campaign exhibited little diurnal variation (Fig. 15b), except for a peak value at 21:00 LST. The collapse of the boundary layer after sunset coupled with fresh local emissions likely contributes to the peak CO at 21:00 LST. On average, the simulated CO is similar to observed except that the model produced a peak at sunset, three hours sooner than observed.

The contributions of $\mathrm{CO}$ from the various source regions in Fig. 15c indicate that emissions from the foothills sources around $\mathrm{T} 1$ contribute most of the $\mathrm{CO}$ above background levels at the T1 site. Even though the local emission rates within $12 \mathrm{~km}$ ( 3 model grid cells) are low compared to those in Sacramento, they are the major contributor to the overprediction in peak $\mathrm{CO}$ around sunset. Sacramento and the Bay Area contribute the remainder of the $\mathrm{CO}$ at the site. In fact, the model suggests that the Bay Area contributes to a relatively larger fraction of $\mathrm{CO}$ than does Sacramento. As the Bay Area pollutants are transported through the Carquinez Strait, the spatial coverage increases as the plume is often split between the Sacramento and San Joaquin Valleys. Daytime upslope flows transport Bay Area pollutants over a large portion of the western Sierra Nevada. In contrast, the Sacramento plume is narrower because of its proximity and changing wind directions during the day often leads to its plume passing over $\mathrm{T} 1$ only for a short period of time (e.g. a few hours) rather than continuously during the day. As might be expected, the influence of the Sacramento and Bay Area sources was nearly zero during the first two trough events.

The average diurnal variation in simulated $\mathrm{CO}$ fraction in Fig. 15d shows that between midnight and sunrise $\sim 50 \%$ of the $\mathrm{CO}$ above background originated from the Bay Area, similar to the predicted fraction over $\mathrm{T} 0$. The fraction of $\mathrm{CO}$ from Sacramento increases during the morning as southwesterly winds develop, with the eastern suburbs peaking one hour sooner at noon because of their closer proximity to T1. Local sources in the foothills contribute to the majority of the T1 peak CO at 18:00 LST. If these local sources are cut in half, the simulated afternoon peak $\mathrm{CO}$ mixing ratios were much closer to observations (not shown).

The contributions from the Sacramento source regions at $\mathrm{T} 1$ provide insight into likely periods of interest to CARES scientists. Table 4 summarizes periods in which Sacramento tracers contributed to greater than $30 \%$ of the total anthropogenic CO. Note that Table 4 is based solely on model predictions and future studies will define in better detail the actual transport periods based on anthropogenic trace gas and aerosol signatures. There are 23 such episodes between 2 and 28 June. "Direct" indicates that the predominant trajectory is 
Table 4. Periods (LST) when the simulated fraction of CO from Sacramento sources at the T1 site is greater than $30 \%$, indicating periods of transport from Sacramento to T1.

\begin{tabular}{|c|c|c|c|c|c|c|c|c|}
\hline Episode & $\begin{array}{l}\text { Start } \\
\text { Day }\end{array}$ & $\begin{array}{l}\text { Start } \\
\text { Hour }\end{array}$ & $\begin{array}{l}\text { End } \\
\text { Day }\end{array}$ & $\begin{array}{l}\text { End } \\
\text { Hour }\end{array}$ & $\begin{array}{r}\text { Peak } \\
\text { Fraction }\end{array}$ & $\begin{array}{r}\text { Peak } \\
\text { Day }\end{array}$ & $\begin{array}{l}\text { Peak } \\
\text { Hour }\end{array}$ & $\begin{array}{l}\text { Sacramento Plume } \\
\text { Transport }\end{array}$ \\
\hline 1 & 2 & 12 & 3 & 3 & 0.76 & 2 & 14 & Direct to T1 \\
\hline 3 & 3 & 23 & 4 & 0 & 0.44 & 3 & 23 & Centerline SE of $\mathrm{T} 1$, then moves through $\mathrm{T} 1$ to $\mathrm{N}$ \\
\hline 4 & 4 & 9 & 4 & 13 & 0.57 & 4 & 10 & Direct to $\mathrm{T} 1$ \\
\hline 5 & 4 & 22 & 5 & 9 & 0.73 & 5 & 3 & Recirculation of aged plume over foothills \\
\hline 8 & 7 & 12 & 8 & 5 & 0.72 & 7 & 13 & Direct to $\mathrm{T} 1$, then moves to the $\mathrm{N}$ \\
\hline 9 & 8 & 13 & 8 & 15 & 0.40 & 8 & 14 & Centerline NW of $\mathrm{T} 1$, then moves to the $\mathrm{N}$ \\
\hline 10 & 9 & 12 & 9 & 17 & 0.74 & 9 & 12 & Direct to $\mathrm{T} 1$, then moves to the $\mathrm{N}$ \\
\hline 11 & 14 & 12 & 14 & 22 & 0.57 & 14 & 13 & Centerline NW of $\mathrm{T} 1$, then moves to the $\mathrm{N}$ \\
\hline 12 & 15 & 12 & 16 & 6 & 0.52 & 15 & 23 & Direct to $\mathrm{T} 1$, then moves $\mathrm{S}$ of $\mathrm{T} 1$, and back again to the $\mathrm{N}$ \\
\hline 17 & 23 & 0 & 23 & 5 & 0.39 & 23 & 4 & Recirculation of aged plume over foothills \\
\hline 18 & 23 & 11 & 24 & 2 & 0.55 & 23 & 16 & Direct to $\mathrm{T} 1$, then moves to the $\mathrm{N}$ \\
\hline 19 & 24 & 12 & 24 & 18 & 0.54 & 24 & 17 & Centerline NW of $\mathrm{T} 1$, then moves to the $\mathrm{N}$ \\
\hline 20 & 25 & 12 & 25 & 21 & 0.55 & 25 & 13 & Centerline SE of T1, then moves $\mathrm{N}$ through $\mathrm{T} 1$ \\
\hline 21 & 26 & 13 & 26 & 20 & 0.55 & 26 & 14 & $\begin{array}{l}\text { Centerline NW of } \mathrm{T} 1 \text {, then moves through } \mathrm{T} 1 \text { to the } \mathrm{S} \text {, and back } \\
\mathrm{N} \text { again }\end{array}$ \\
\hline 22 & 27 & 12 & 27 & 13 & 0.39 & 27 & 13 & Centerline SE of T1, and stays to the $\mathrm{S}$ \\
\hline 23 & 28 & 10 & 28 & 14 & 0.45 & 28 & 11 & Centerline SE of $\mathrm{T} 1$, and stays to the $\mathrm{S}$ \\
\hline
\end{tabular}

a straight line from Sacramento to T1. However, the transport pathway on most days is not direct. The Sacramento plume is often transported towards the northeast during the morning and passes northwest of the $\mathrm{T} 1$ site. As wind directions become more westerly during the afternoon, the Sacramento plume moves to the south and sweeps over the T1 site. On other days, the plume centerline is south of the T1 site. And on other days, the plume centerline can move across the T1 site more than once. Some of the periods listed in Table 4 are during the evening and early morning when $\mathrm{CO}$ that has been transported into the foothills is simply being recirculated around the region by light and variable winds. Thus, the air mass trajectories may follow either a circuitous route or a direct route from Sacramento to T1.

\section{Regional recirculation of tracers}

In addition to diurnally-varying slope flows near the surface resulting from the heating and cooling along the mountains, compensating flows aloft likely affect the transport and mixing of pollutants in the region. By coupling model predictions with measurements collected during CARES, recirculation at night is shown to likely transport aged trace gases and aerosols from the western slopes of the Sierra Nevada back over Sacramento. The layers of aged trace gases and aerosols are subsequently entrained into the growing convective boundary layer the following day. The processes and sources contributing to pollutants in the valley atmosphere above the boundary layer are illustrated in Figs. 16-18.

Figure 16a depicts the simulated profile of $\mathrm{CO}$ over the T0 site during the entire campaign. To eliminate fresh emissions, only the corresponding column burden of $\mathrm{CO}$ above the boundary layer is shown in Fig. 16b. The fraction of CO above the boundary layer originating from various source regions is shown in Fig. 16c. Prior to the first major upper-level trough, the model suggests that some anthropogenic emissions remain in the region and the majority of the $\mathrm{CO}$ aloft originates from Sacramento and the Bay Area. As the first major trough passes over California between 11 and 13 June, the amount of $\mathrm{CO}$ aloft is reduced significantly because the strong northerly winds transport only emissions from smaller sources in the Sacramento Valley and from the foothills of the Sierra Nevada over Sacramento. After the trough moves to the east, the meteorological conditions permit $\mathrm{CO}$ to increase aloft for two days, until the second major upper-level trough on 16 June again quickly transports CO from Sacramento towards the San Joaquin Valley. After the second major trough, the amount of $\mathrm{CO}$ aloft gradually increases during 

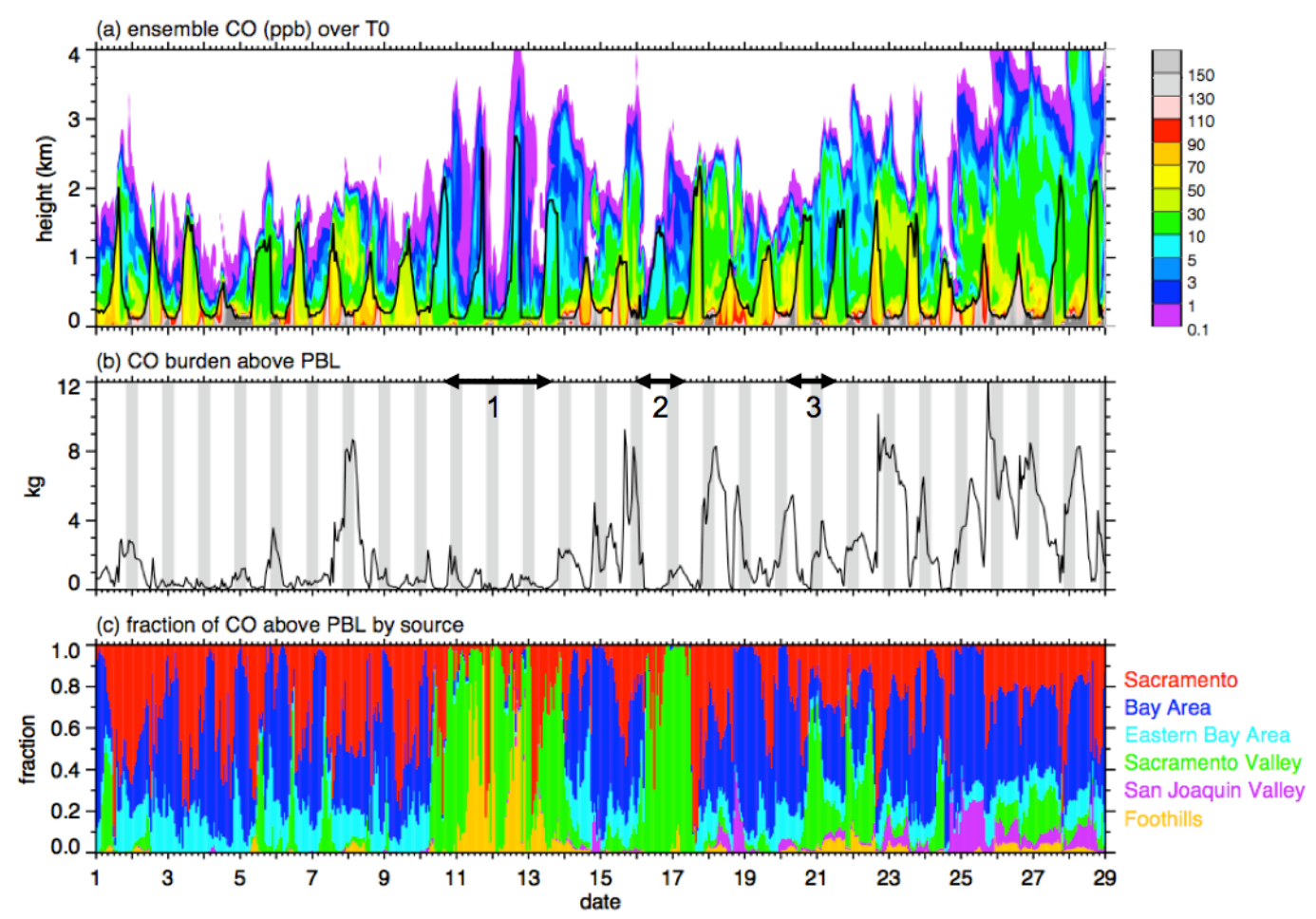

Fig. 16. (a) Simulated CO profile over the TO site during the campaign, (b) total CO column burden above the boundary layer (BL), and (c) fraction of CO above the BL by source region. Black line in (a) is the simulated boundary-layer height and shading in (b) denotes nighttime periods. Arrows denote three periods of northwesterly synoptic flow.

the remainder of the month. The third major trough on 20 June was too weak and brief to significantly reduce CO levels. During this period the amount of $\mathrm{CO}$ from the foothills sources is higher than prior to the first major trough and emissions from the San Joaquin Valley are present. Although the fraction of $\mathrm{CO}$ from these two source regions is small compared to emissions from Sacramento, the Sacramento Valley, and the Bay Area, the model indicates that transport and mixing patterns after the second major trough were different from those prior to 10 June.

The temporal evolution of the simulated 3-D wind and boundary layer structure was examined to determine the processes responsible for the layers of $\mathrm{CO}$ aloft. An example is shown in Fig. 17 between 16:00 and 22:00 LST on 22 June. Figure 16a and $b$ show that the morning of 23 June was one of the periods with the highest amount of $\mathrm{CO}$ above the morning boundary layer in Sacramento.

Southwesterly upslope flows transported CO from Sacramento and the Bay Area over western slopes of the Sierra Nevada Mountains during the afternoon of 22 June. Above the convective boundary layer, an easterly compensating flow was produced by the model (not shown). This compensating flow is a common feature predicted by mesoscale models in complex terrain (e.g. Mahrer and Pielke, 1977; Rampanelli et al., 2004), but few observations over terrain slopes and at these altitudes have been available to directly verify such predictions (Whiteman, 1990; Zardi and Whiteman, 2012). The vertical wind shear between the two flows could also generate mechanical turbulence and mix trace gases and aerosols. During the early evening as the boundary layer collapses, some of the $\mathrm{CO}$ remains in the residual layer. A portion of the $\mathrm{CO}$ over the mountain slopes is transported back toward the west forming layers aloft over valley floor (Fig. 17a) by 22:00 LST, as the upslope flow weakens and easterly flow aloft descends to lower altitudes during the early evening. At this time over the lower slopes of the Sierra Nevada, the model produces easterly downslope flow adjacent to the surface, westerly upslope flow persisting from the afternoon above the surface layer to $0.7 \mathrm{~km}$ a.g.l., and easterly flow between 0.7 and $1.5 \mathrm{~km}$ a.g.l. (Fig. 17b). Winds from the radar wind profiler deployed at the T1 site from 16 to 22:00 LST (Fig. 17c) show that the wind directions were southwesterly between 0.2 and $0.9 \mathrm{~km} \mathrm{~m}$.s.l. and southeasterly between 0.9 and $1.8 \mathrm{~km}$ a.g.l. The simulated wind profiles during this period were qualitatively similar to the measurements, although there are differences in the speed and direction at specific times. Measurements from the Sacramento radar wind profiler (Fig. 17d) indicate that the winds aloft between 1 and $2 \mathrm{~km}$ m.s.l. were light and variable during this period. Both the measurements and modeling suggest that easterly flow 
(a) cross-section of $\mathrm{CO}(\mathrm{ppb})$ from all sources through TO site

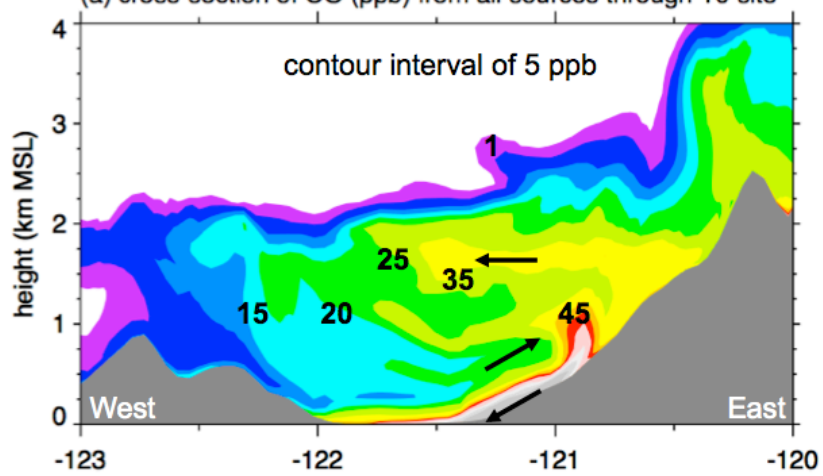

(b) cross-section of wind direction through TO site

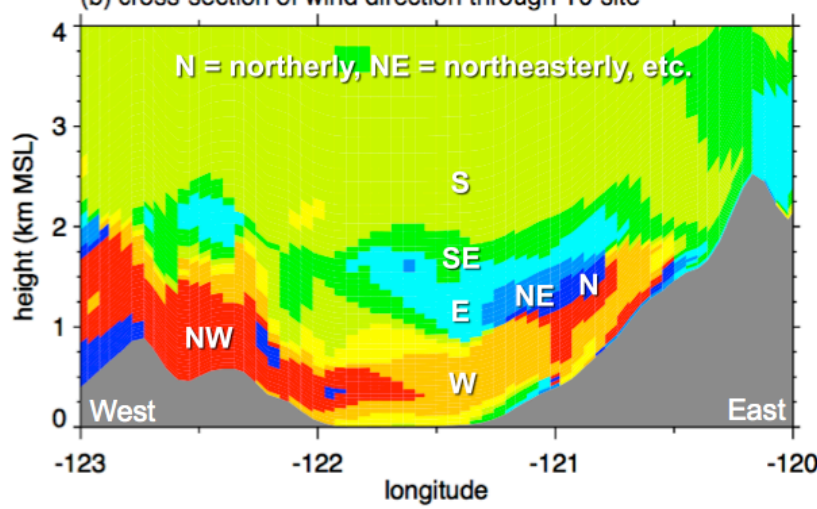

(c) wind profiles at T1 site, 16 - 22 LST

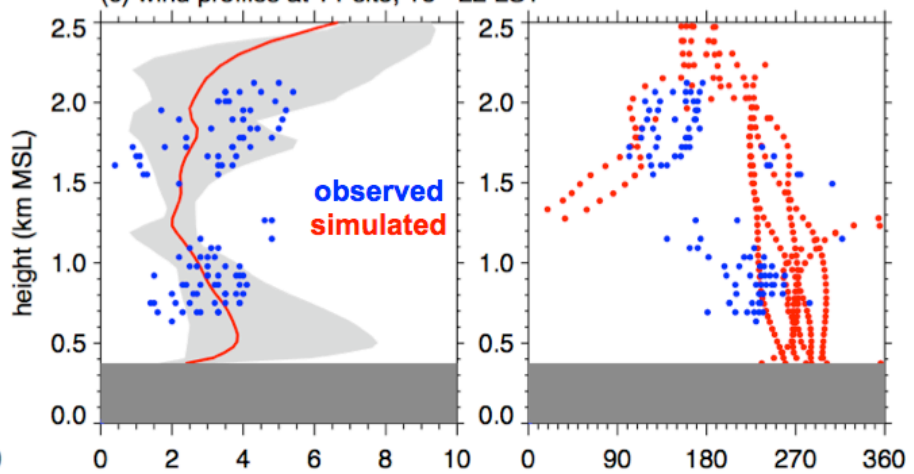

(d) wind profiles at TO site, 16 - 22 LST

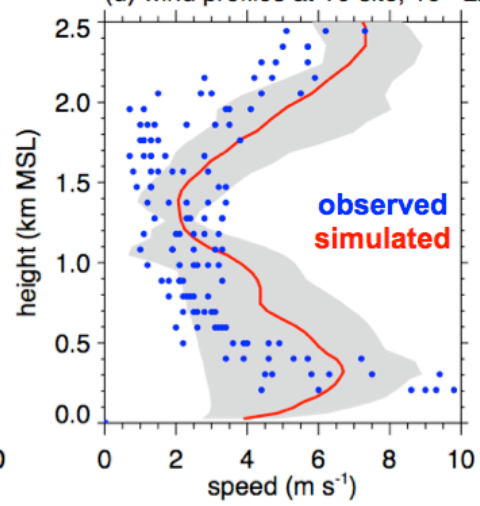

Fig. 17. West-east vertical cross sections through the T0 site at 22:00 LST for (a) CO from all anthropogenic sources and (b) simulated wind direction (denoted by N, NE, E, SE, S, SW, W, and NW). Observed radar wind profiler (blue) and simulated (red) wind speed and direction profiles at the (c) T1 and (d) T0 sites between 17 and 23 PDT, 22 June. Dark gray shading denotes terrain height and light gray shading in (c) and (d) denote range of simulated values.

aloft over the lower mountain slopes converges with the light winds over the valley center during the evening. After midnight, the layer of easterly winds aloft gradually diminishes and becomes light and variable (not shown). Thus, the recirculation pattern and light winds aloft are responsible for $\mathrm{CO}$ remaining in the valley atmosphere by next morning. This reservoir of $\mathrm{CO}$ subsequently contributes to surface values through entrainment into the growing convective boundary layer the next day.

The process described above is known as the "mountain chimney effect" or "mountain venting", first described by Lu and Turco (1996) for ozone plumes in Los Angeles. Langford et al. (2010) presented measurements from an airborne ozone lidar that recently provided evidence of ozone layers aloft resulting from mountain venting. The recirculation pattern and transport of $\mathrm{CO}$ into the free atmosphere in this study is similar, except that the terrain geometry and local meteorology is different from the Los Angeles basin. Venting of boundary layer aerosols into the free atmosphere has been observed by lidars in other regions, such as over central Mexico (Fast et al., 2011) and over the Alps (Neyki et al., 2000; Henne et al., 2004).
Aerosol layers were observed by the HSRL on the B200 aircraft over central California during the morning on many days. Figure 18a depicts aerosol backscatter profiles along the B-200 flight path (Fig. 18c) during the late morning of 23 June between 09:00 and 11:00 LST. While the highest backscatter in the valley occurred within the convective boundary layer up to $0.5 \mathrm{~km} \mathrm{~m}$.s.l., layers of aerosols were observed above the boundary layer and below $2.5 \mathrm{~km}$ m.s.l. The simulated CO layers aloft along the B-200 flight path (Fig. 18b) are consistent with the aerosol backscatter measurements, resulting from the processes described in Fig. 17. Although the operational WRF-Chem forecasts did not simulate aerosol evolution, these results indicate that the recirculation of local anthropogenic emissions is a process contributing to these aerosol layers. These aerosol layers are likely influenced by biogenic sources during transport over the Sierra Nevada.

The operational WRF-Chem forecasts coupled with observed wind profiles and HSRL data show that the model is able to simulate the processes responsible for producing layers aloft above the Sacramento Valley. Our next step will be to use WRF-Chem in a similar configuration to simulate 

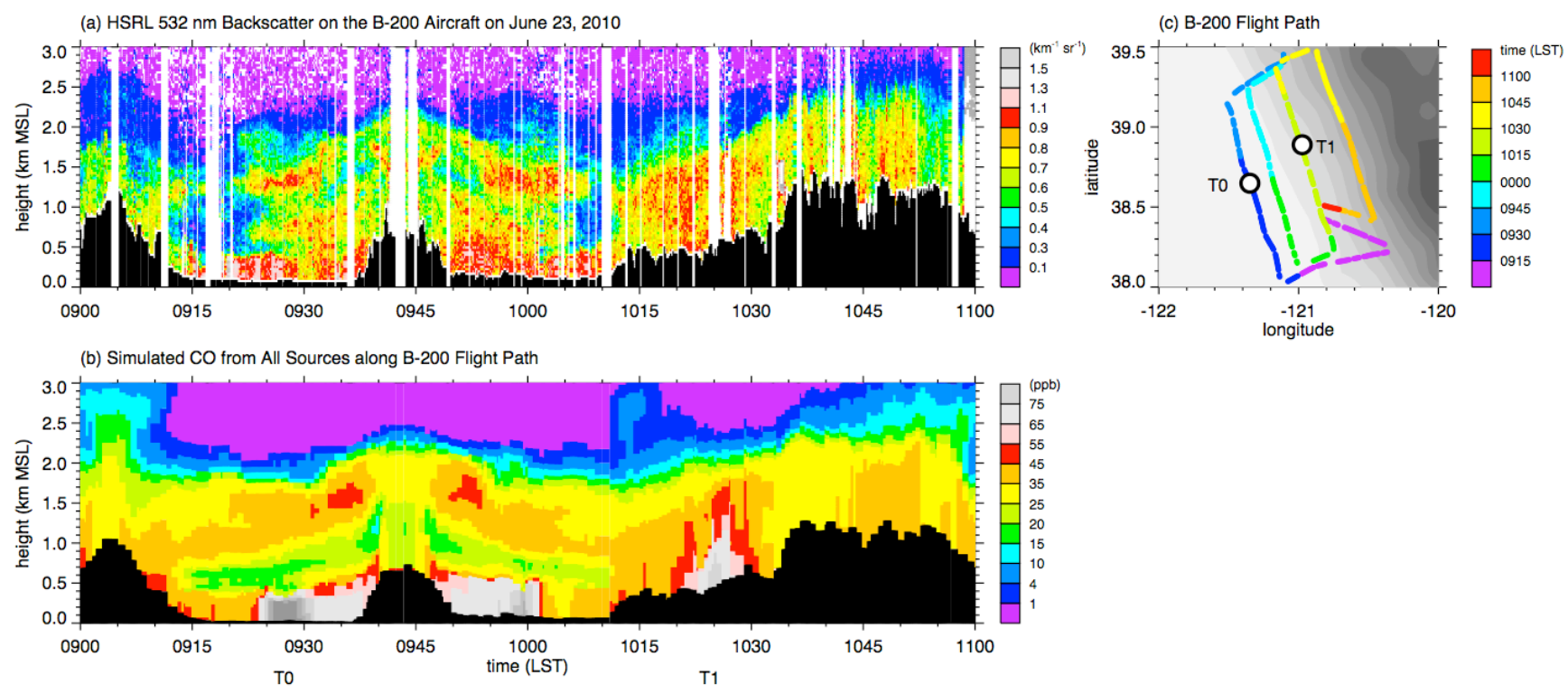

Fig. 18. Observed and simulated quantities along the B-200 flight during the morning of 23 June including (a) observed backscatter and (b) simulated CO from all sources. (c) B200 flight path divided into 15-min segments denoted by colors and gray shading is topography. White areas in (a) denote missing data or negative backscatter values while black areas in (a) and (b) denote topography.

the emissions, transport, mixing, chemical transformation, and deposition of aerosols to determine the relative role of aerosol chemistry in relation to meteorological processes that govern aerosol evolution in the Sacramento Valley.

\section{Summary}

A combination of measurements and modeling was used to describe the overall meteorological conditions that affected the transport and mixing of trace gases and aerosols in the vicinity of Sacramento, California during the June 2010 CARES campaign. The anticipated thermally-driven flows, favorable for transport of pollutants from the city (site T0) to the downwind sampling site in the foothills of the Sierra Nevada (site T1), were observed during CARES. However, the passage of mid-tropospheric troughs over California disrupted these local flows during three periods: 10-13 June, 16-17 June, and 20-21 June. The troughs produced northwesterly near surface winds, transporting pollutants emitted from Sacramento into the San Joaquin Valley and significantly reducing local pollutant concentrations. The winds were particularly strong, exceeding $15 \mathrm{~m} \mathrm{~s}^{-1}$, on 11,12 , and 16 June. The meteorological conditions after the passage of the third upper-level trough, from 22 to 28 June, were the most favorable for photochemistry and likely SOA formation. Mostly sunny conditions with periods of thin cirrus clouds were observed during the campaign; 4 and 24 June were the only days during which clouds significantly reduced incoming shortwave radiation.
To support aircraft sampling during the campaign, the WRF-Chem model was used to forecast the spatial distribution and temporal variation of $\mathrm{CO}$ emitted from 20 source regions. We showed that the forecasted diurnal and multi-day variations in near-surface temperature, humidity, and winds at the surface and aloft were in reasonable agreement with the observations. Errors in the near-surface simulated wind speed associated with the daytime upslope flows at $\mathrm{T} 1$ were somewhat larger than over the center of the valley. The vertical extent of boundary layer mixing is an important meteorological process that affects the dilution of trace gases and aerosols near the surface. Observed and simulated afternoon boundary layer depths were usually less than $2 \mathrm{~km}$ during CARES. The mean simulated boundary-layer depth at 16 LST during the campaign was 44 and $188 \mathrm{~m}$ higher than the mean radiosonde observations at the $\mathrm{T} 0$ and $\mathrm{T} 1$ sites, respectively. The simulated boundary-layer depths were usually within $30 \%$ of those derived from radiosonde observations, which is typical of those produced by current boundarylayer parameterizations. Some of these differences can be attributed to errors in the boundary-layer growth rate produced by the model that is affected by predicted ambient temperatures, surface heat fluxes, as well as the treatment of vertical mixing.

Forecasts of the downwind Sacramento CO plume position were also in reasonable agreement with aircraft measurements on most days because the predicted meteorology was similar to observed. The observed and simulated median and range of $\mathrm{CO}$ mixing ratios were similar at altitudes below $0.5 \mathrm{~km}$ m.s.l.; however, simulated $\mathrm{CO}$ was somewhat 
lower than observed at most altitudes above $0.5 \mathrm{~km}$. While the forecasts were useful in the field to confirm that the downwind aircraft transects would intersect emissions from Sacramento, the simulated $\mathrm{CO}$ tagged by source region provides a means of examining how trace gases and aerosols are likely transported and mixed together in the region. The main findings from the analysis of the simulated $\mathrm{CO}$ tracers are:

- Emissions from the San Francisco Bay Area contributed on average 40 to $50 \%$ of the $\mathrm{CO}$ over the T0 site between midnight and 06:00 LST. As local emission rates increased during the morning, the average fraction of Bay Area emissions decreased to about $20 \%$ during the day. Bay Area emissions were absent over Sacramento and the T1 site only during the three trough events with associated northwesterly winds.

- The fraction of CO originating from Sacramento and Bay Area sources increases at the T1 site during the morning and peaks on average in the early afternoon between 12:00 and 13:00 LST. CO mixing ratios remain relatively constant during the day as transport is offset by dilution associated with the growing convective boundary layer. A surprisingly large fraction of the $\mathrm{CO}$ above background over the $\mathrm{T} 1$ site originated from sources in nearby cities. Local emissions produced simulated peak $\mathrm{CO}$ mixing ratios between 18 and 19:00 LST; however, the observed peak CO occurred at 21:00 LST.

- Simulated transport of CO from Sacramento to the T1 site occurred during 23 periods throughout the campaign. Three of these periods occurred at night as $\mathrm{CO}$ previously transported east of $\mathrm{T} 1$ came back over the site.

- Daytime transport from Sacramento directly to the T1 site only occurred on 8 days. An equally likely scenario was for Sacramento CO to be transported northward by light southerly winds in the valley during the morning. As southwesterly winds developed during the day, the plume centerline shifted to the south and east, sweeping over the $\mathrm{T} 1$ site. The opposite sweeping pattern from south to north during the day was not frequent.

- The model likely predicted the arrival of Sacramento emissions at the $\mathrm{T} 1$ site earlier than in reality, because the simulated upslope wind speeds over the foothills were somewhat higher than observed.

- Mountain-venting processes contributed to aged pollutants aloft in the valley atmosphere that can be entrained into the growing boundary layer the subsequent day. This circulation pattern will mix aged pollutants with fresh emissions. As far as we know, this is the first time this phenomenon has been observed and simulated along the eastern slopes of the Sierra Nevada.
- The model suggests that it was possible for San Joaquin Valley emissions to be transported to the Sacramento Valley during the latter part of the campaign, but the levels were small compared to contributions from local emissions.

The results presented here can be used to interpret time series of trace gases and aerosols sampled at the T1 site that will be described in other studies. Analysis of the measurements will provide additional evidence of when transport of anthropogenic emissions from Sacramento occurred. Our results also stress the importance of specifying the chemical boundary conditions using predictions from global models to account for long-range transport that likely influences some trace gas and aerosol species over California.

In a future study, the WRF-Chem model will be used to assess its ability to simulate aerosol evolution in the region. Of particular interest is how well new treatments of primary and secondary organic aerosols represent observations of organics and their optical and hygroscopic properties using the extensive surface and airborne measurements collected during CARES coupled with the CalNex dataset.

Acknowledgements. We thank the numerous scientists, pilots, and other staff that contributed to the data collection during CARES. Data were obtained from the Atmospheric Radiation Measurement (ARM) Program sponsored by the US Department of Energy, Office of Science, Office of Biological and Environmental Research (OBER), Climate and Environmental Sciences Division. We also thank the staff at Northside School in Cool and American River College, particularly Wendy Westsmith and Laduan Smedley, for the use of their facilities. Elaine Chapman provided valuable comments on the content of this paper. This research was supported by the US DOE's Atmospheric Science Research (ASR) Program under Contract DE-AC06-76RLO 1830 at Pacific Northwest National Laboratory (PNNL). PNNL is operated for the US DOE by Battelle Memorial Institute.

Edited by: G. McFiggans

\section{References}

Abatzoglou, J. T., Redmond, K. T., and Edward, L. M.: Classification of regional climate variability in the state of California, J. Appl. Meteor. Clim., 48, 1527-1541, 2009.

Bao, J.-W., Michelson, S. A., Persson, P. O. G., Djalavoa, I. V., and Wilczak, J. M.: Observed and WRF-simulated low-level winds in a high-ozone episode during the Central California Ozone Study, J. Appl. Meteor. Clim., 47, 2372-2394, 2008.

Bouvier-Brown, N. C., Goldstein, A. H., Gilman, J. B., Kuster, W. C., and de Gouw, J. A.: In-situ ambient quantification of monoterpenes, sesquiterpenes, and related oxygenated compounds during BEARPEX 2007: implications for gas- and particle-phase chemistry, Atmos. Chem. Phys., 9, 5505-5518, doi:10.5194/acp-9-5505-2009, 2009. 
Brooks, I. M.: Finding boundary layer top: Application of wavelet covariance transform to Lidar backscatter profiles, J. Atmos. Ocean. Tech., 20, 1092-1105, 2003.

Cooper, O. R., Oltmans, S. J., Johnson, B. J. Brioude, J., Angevine, W., Trainer, M., Parrish, D. D., Ryerson, T. R., I. Pollack, I., Cullis, P. D., Ives, M. A., Tarasick, D. W., AlSaadi, J., and Stajner, I.: Measurement of western US baseline ozone from the surface to the tropopause and assessment of downwind impact regions, J. Geophys. Res., 116, D00V03, doi:10.1029/2011JD016095, 2011.

Croes B. E. and Fujita, E. M.: Overview of the 1997 Southern California Ozone Study (SCOS970-NARSTO), Atmos. Environ., 37, supplement No. 2, S3-S26, 2003.

Dabdub, D., DeHaan, L. L., and Seinfeld, J. H.: Analysis of ozone in the San Joaquin Valley of California, Atmos. Environ., 33, 2501-2514, 1999.

Doran, J. C., Fast, J. D., Barnard, J. C., Laskin, A., Desyaterik, Y., and Gilles, M. K.: Applications of lagrangian dispersion modeling to the analysis of changes in the specific absorption of elemental carbon, Atmos. Chem. Phys., 8, 1377-1389, doi:10.5194/acp-8-1377-2008, 2008.

Fast, J. D., Gustafson Jr., W. I., Easter, R. C., Zaveri, R. A., Barnard, J. C., Chapman, E. G., and Grell, G. A.: Evolution of ozone, particulates, and aerosol direct forcing in an urban area using a new fully-coupled meteorology, chemistry, and aerosol model, J. Geophys. Res., 111, D21305, doi:10.1029/2005JD006721, 2006.

Fast, J. D., Gustafson Jr., W. I., Chapman, E. G., Easter, R. C., Rishel, J., Zaveri, R. A., Grell, G., and Barth, M.: The Aerosol Modeling Testbed: A community tool to objectively evaluate aerosol process modules, Bull. Amer. Meteor. Soc., 92, 343-360, 2011.

Grell, G. A., Peckham, S. E., Schmitz, R., McKeen, S. A., Frost, G., Skamarock, W. C., and Eder, B.: Fully coupled "online" chemistry within the WRF model, Atmos. Environ., 39, 6957-6976, 2005.

Hair, J. W., Hostetler, C. A., Cook, A. L., Harper, D. B., Ferrare, R. A., Mack, T. L., Welch, W., Izquierdo, L. R., and Hovis, F. E.: Airborne high spectral resolution Lidar for profiling aerosol optical properties, Appl. Optics, 47, doi:10.1364/AO.47.006734, 2008.

Henne, S., Furger, M., Nyeki, S., Steinbacher, M., Neininger, B., de Wekker, S. F. J., Dommen, J., Spichtinger, N., Stohl, A., and Prvt, A. S. H.: Quantification of topographic venting of boundary layer air to the free troposphere, Atmos. Chem. Phys., 4, 497509, doi:10.5194/acp-4-497-2004, 2004.

Huang, M., Carmichael, G. R., Adhikary, B., Spak, S. N., Kulkarni, S., Cheng, Y. F., Wei, C., Tang, Y., Parrish, D. D., Oltmans, S. J., D’Allura, A., Kaduwela, A., Cai, C., Weinheimer, A. J., Wong, M., Pierce, R. B., Al-Saadi, J. A., Streets, D. G., and Zhang, Q.: Impacts of transported background ozone on California air quality during the ARCTAS-CARB period a multi-scale modeling study, Atmos. Chem. Phys., 10, 6947-6968, doi:10.5194/acp-106947-2010, 2010.

Jaffe, D., Anderson, T., Covert, D., Kotchenruther, R., Trost, B., Danielson, J., Simpson, W., Berntsen, T, Karlsdottir, S., Blake, D., Harris, J., Carmichael, G., and Uno, I.: Transport of Asian air pollution to North America, Geophys. Res. Lett., 26, 711$714,1999$.
Jacob, D. J., Crawford, J. H., Maring, H., Clarke, A. D., Dibb, J. E., Emmons, L. K., Ferrare, R. A., Hostetler, C. A., Russell, P. B., Singh, H. B., Thompson, A. M., Shaw, G. E., McCauley, E., Pederson, J. R., and Fisher, J. A.: The Arctic Research of the Composition of the Troposphere from Aircraft and Satellites (ARCTAS) mission: design, execution, and first results, Atmos. Chem. Phys., 10, 5191-5212, doi:10.5194/acp-10-5191-2010, 2010.

Jacobson, M. Z.: GATOR-GCMM 2. A study of daytime and nighttime ozone layers aloft, ozone in national parks, and weather during SARMAP field campaign, J. Geophys. Res., 106, 54035420. 2011.

Jimenez, J. L., Canagaratna, M. R., Donahue, N. M., Prevot, A. S. H., Zhang, Q., Kroll, J. H., DeCarlo, P. F., Allan, J. D., Coe, H., Ng, N. L., Aiken, A. C., Doherty, K. S., Ulbrich, I. M., Grieshop, A. P., Robinson, A. L., Duplissy, J., Smith, J. D., Wilson, K. R., Lanz, V. A., Hueglin, C., Sun, Y. L., Tian, J., Laaksonen, A., Raatikainen, T., Rautiainen, J., Vaattovaara, P., Ehn, M., Kulmala, M., Tomlinson, J. M., Collins, D. R., Cubison, M. J., Dunlea, E. J., Huffman, J. A., Onasch, T. B., Alfarra, M. R., Williams, P. I., Bower, K., Kondo, Y., Schneider, J., Drewnick, F., Borrmann, S., Weimer, S., Demerjian, K., Salcedo, D., Cottrell, L., Griffin, R., Takami, A., Miyoshi, T., Hatakeyama, S., Shimono, A., Sun, J. Y., Zhang, Y. M., Dzepina, K., Kimmel, J. R., Sueper, D., Jayne, J. T., Herndon, S. C., Trimborn, A. M., Williams, L. R., Wood, E. C., Middlebrook, A. M., Kolb, C. E., Baltensperger, U., and Worsnop, D. R.: Evolution of organic aerosols in the atmosphere, Science, 326, 1524-1529, 2009.

Jin, L., Brown, N. J., Harley, R. A., Bao, J.-W., Michelson, S. A., and Wilczak, J. M.: Seasonal versus episodic performance evaluation for an Eulerian photochemical model, J. Geophys. Res., 115, D09302, doi:10.1029/2009JD012680, 2010.

Kang, D., Mathur, R., and Rao, S.T.: Assessment of the biasadjusted PM2.5 air quality forecast over the continental United States during 2007, Geosci. Model Dev., 3, 309-320, 2010.

Kinne, S., Schulz, M., Textor, C., Guibert, S., Balkanski, Y., Bauer, S. E., Berntsen, T., Berglen, T. F., Boucher, O., Chin, M., Collins, W., Dentener, F., Diehl, T., Easter, R., Feichter, J., Fillmore, D., Ghan, S., Ginoux, P., Gong, S., Grini, A., Hendricks, J., Herzog, M., Horowitz, L., Isaksen, I., Iversen, T., Kirkevg, A., Kloster, S., Koch, D., Kristjansson, J. E., Krol, M., Lauer, A., Lamarque, J. F., Lesins, G., Liu, X., Lohmann, U., Montanaro, V., Myhre, G., Penner, J., Pitari, G., Reddy, S., Seland, O., Stier, P., Takemura, T., and Tie, X.: An AeroCom initial assessment - optical properties in aerosol component modules of global models, Atmos. Chem. Phys., 6, 1815-1834, doi:10.5194/acp-6-1815-2006, 2006.

Lagarias, J. S. and Sylte, W. W.: Designing and managing the San Joaquin Valley air quality study, J. Air Waste Manage. Assoc., 41, 1176-1179, 1991.

Langford, A. O., Senff, C. J., Alvarez, R. J., Banta, R. M., and Hardesty, R. M.: Long-range transport of ozone from the Los Angeles Basin: A case study, Geophys. Res. Lett., 37, L068072, doi:10.1029/2010GL042507, 2010.

Lawson, D. R.: The southern California air quality study, J. Air Waste Manage. Assoc., 40, 156-165, 1990.

Lu, R. and Turco, R.P.: Ozone distributions over the Los Angeles Basin: Three-dimensional simulations with the SMOG model, Atmos. Environ., 30, 4155-4176, doi:10.1016/13522310(96)00153-7, 1996. 
Mahrer, Y. and Pielke, R. A.: The effects of topography on sea and land breezes in a two-dimensional numerical model, Mon. Weather Rev., 105, 1151-1162, 1977.

Mangold, A., De Backer, H., De Paepe, B., Dewitte, S., Chiapello, I., Derimian, Y., Kacenelenbogen, M., Léon, J.-F., Huneeus, N., Schulz, M., Ceburnis, D., O'Dowd, C., Flentje, H,. Kinne, S., Benedetti, A., Morcrette, J.-J., and Boucher, O.: Aerosol analysis and forecast in the European Centre for Medium-Range Weather Forecasts integrated system: 3. Evaluation by means of case studies, J. Geophys. Res., 116, D03302, doi:10.1029/2010JD014864, 2011.

Mathur, R., Yu, S., Kang, D., and Schere, K. L.: Assessment of the wintertime performance of developmental particulate matter forecasts with the Eta-Community Multiscale Air Quality modeling system, J. Geophys. Res., 113, D02303, doi:10.1029/2007JD008580, 2008.

McKeen, S., Chung, S.H., Wilczak, J., Grell, G., Djalaova, I., Peckham, S., Gong, W., Bouchet, V., Moffet, R., Tang, Y., Carmicheal, G.R., Mathur, R., and Yu, S.: Evaluation of several PM2.5 forecast models using data collected during the ICARTT/NEAQS 2004 field study, J. Geophys. Res., 112, D10S20, doi:1029/2006JD007608, 2007.

McKeen, S., Grell, G., Peckham, S., Wilzak, J., Djalaova, I., Hsie, E.-Y., Frost, G., Peischl, J., Spackman, R., Holloway, J., de Gouw, J., Warnetke, C., Gong, W., Bouchet, V., Gardreault, S., Racine, J., McHenry, J., McQueen, J., Lee, P., Tang, Y., Carmichael, G. R., and Mathur, R.: An evaluation of real-time air quality forecasts and their urban emissions over eastern Texas during the summer of 2006 Second Texas Air Quality Study field study, J. Geophys. Res., 114, D00F11, doi:10.1029/2008JD011697, 2009.

Michelson, S. A., Djalaova, I. V., Bao, J.-W.: Evaluation of summertime low-level winds simulated by MM5 in the Central Valley of Califonia, J. Appl. Met. Clim., 49, 2230-2245, 2010.

Molina, L. T., Madronich, S., Gaffney, J. S., Apel, E., de Foy, B., Fast, J., Ferrare, R., Herndon, S., Jimenez, J. L., Lamb, B., Osornio-Vargas, A. R., Russell, P., Schauer, J. J., Stevens, P. S., Volkamer, R., and Zavala, M.: An overview of the MILAGRO 2006 Campaign: Mexico City emissions and their transport and transformation, Atmos. Chem. Phys., 10, 8697-8760, doi:10.5194/acp-10-8697-2010, 2010.

Murphy, J. G., Day, D. A., Cleary, P. A., Wooldridge, P. J., and Cohen, R. C.: Observations of the diurnal and seasonal trends in nitrogen oxides in the western Sierra Nevada, Atmos. Chem. Phys., 6, 5321-5338, doi:10.5194/acp-6-5321-2006, 2006.

Nyeki, S., Kalberer, M., Colbeck, I., De Wekker, S., Furger, M., Gaggeler, H.W., Kossman, M., Lugauer, M., Steyn, D., Weingartner, E., Wirth, M., and Baltensperger, U.: Convective boundary layer evolution to $4 \mathrm{~km}$ asl over high-alpine terrain: Airborne lidar observations in the Alps, Geophys. Res., Lett., 27, 689-692, 2000.

Otte, T. L., Pouliot, G., Pleim, J. E., Young, Y. O., Schere, K. L., Wong, D. C., Lee, P. C. S., Tsidulko, M., McQueen, J. T., Davidson, J. T., Mathur, R., Chuang, H. Y., DiMego, G., and Seaman, N. L.: Linking the Eta Model with the Community Multiscale Air Quality (CMAQ) Modeling System to Build a National Air Quality Forecasting System, Weather Forecast., 20, 367-384, 2005.
Pfister, G. G., Avise, J., Wiedinmyer, C., Edwards, D. P., Emmons, L. K., Diskin, G. D., Podolske, J., and Wisthaler, A.: CO source contribution analysis for California during ARCTAS-CARB, Atmos. Chem. Phys., 11, 7515-7532, doi:10.5194/acp-11-75152011, 2011.

Pierce, R. B., Schaack, T., Al-Saadi, J. A., Fairlie, T. D., Kittaka, C., Lingenfelser, G., Natarajan, M., Olson, J., Soja, A., Zapotocny, T., Lenzen, A., Stoble J., Johnson, D., Avery, M. A., Sachse, G. W., Thompson, A., Cohen, R., Dibb, J. E. Crawford, J., Rault, D., Martin, R., Szykman, J., and Fishman, J.: Chemical data assimilation estimates of continental US ozone and nitrogen budgets during the Intercontinental Chemical Transport Experiment-North America, J. Geophys. Res., 112, D12S21, doi:10.1029/2006JD007722, 2007.

Rampanelli G., Zardi, D., and Rotunno, R.: Mechanisms of upvalley winds, J. Atmos. Sci., 61, 3097-3111, 2004.

Seaman, N. L., Stauffer, D.R., and Lario-Gibbs, A. M.: A multiscale four-dimensional data assimilation system applied in the San Joaquin Valley during SARMAP. Part I: Modeling design and basic performance characteristics, J. Appl. Meteorol., 34, 1739-1761, 1995.

Shaw, W. J., Pekour, M. S., Coulter, R. L., Martin, T. J., and Walters, J. T.: The daytime mixing layer observed by radiosonde, profiler, and lidar during MILAGRO, Atmos. Chem. Phys. Discuss., 7, 15025-15065, doi:10.5194/acpd-7-15025-2007, 2007.

Solomon, S., Qin, D., Manning, M., Marquis, M., Averyt, K., Tignor, M. M. B., Miller Jr., H. L., and Chen, Z. (Eds.): Climate Change 2007: The Physical Science Basis, Cambridge University Press, 996 pp., 2007.

Van Pul, W. A. J., Holtslag, A. A. M., and Swart, D. P. J.: A comparison of ABL heights inferred routinely from lidar and radiosondes at noontime, Bound.-Layer Meteorol., 68, 173-191, 1994.

Volkamer, R., Jimenez, J. L., San Martini, F., Dzepina, K., Zhang, Q., Salcedo, D., Mollina, L. T., Worsnop, D. R., and Molina, M. J.: Secondary organic aerosol formation from anthropogenic air pollution: Rapid and higher than expected, Geophys. Res. Lett., 33, L17811, doi:10.1029/2006GL026899, 2006.

Weber, R. J., Sullivan, A. P., Peltier, R. E., Russell, A., Yan, B., Zheng, M., de Gouw, J., Warneke, C., Brock, C., Holloway, J. S., Atlas, E. L., and Edgerton, E.: A study of secondary organic aerosol formation in the anthropogenicinfluenced southeastern United States, J. Geophys. Res., 112, D13302, doi:101029/2007JD008408, 2007.

White, A. B., Senff, C. J., and Banta, R. M.: A comparison of mixing depths observed by ground-based wind profilers and an airborne lidar, J. Atmos. Ocean. Technol., 16, 584-590, 1999.

Whiteman, C. D.: Observations of thermally developed wind systems in mountainous terrain. Chapter 2 in: Atmospheric Processes over Complex Terrain, edited by: Blumen, W., Meteor. Mon., 23, 5-42, Published by Amer. Meteor. Soc., Boston, MA, 1990.

Vaden, T. D., Imre, D., Beranek, J., Shrivastava, M., and Zelenyuk, A.: Evaporation kinetics and phase of laboratory and ambient secondary organic aerosol, Proc. Natl. Acad. Sci., 108, 21902195, doi:10.1073/pnas.1013391108, 2011.

Yu, S., Mathur, R., Schere, K., Kang, D., Pleim, J., Young, J., Tong, D., Pouliot, G., McKeen, S.A., and Rao, S.T.: Evaluation or real-time $\mathrm{PM}_{2.5}$ forecasts and process analysis for $\mathrm{PM}_{2.5}$ formatoin over the eastern United States using the Eta-CMAQ 
forecast model during 2004 ICARTT study, J. Geophys. Res., 113, D06204, doi:10.1029/2007JD009226, 2008.

Zardi, D. and Whiteman, C. D.: Diurnal mountain wind systems, chapter 2 in: Mountain Weather Research and Forecasting, edited by: Chow F. K., Snyder, B., and DeWekker S. F. J., Springer Atmospheric Sciences, ISBN 978-94-007-4097-6, 722 pp., 2012.

Zaveri, R. A., Shaw, W. J., Cziczo, D. J., Schmid, B., Ferrare, R. A., Alexander, M. L., Alexandrov, M., Arnott, W. P., Atkinson, D., Barnard, J. C., Berg, L. K., Beranek, J., Cairns, B., Comstock, J., Dubey, M. K., Easter, R. C., Erickson, M., Fast, J. D., Floerchinger, C., Flowers, B. A., Fortner, E., Gaffney, J., Gilles, M. K., Gyawali, M., Hair, J., Herndon, S., Hostetler, C., Hubbe, J.
M., Jayne, J. T., Jobson, B. T., Kassianov, E., Kleinman, L. I. Kluzek, C., Knighton, B., Kubatova, A., Kuang, C., Laskin, A., Laulainen, N., Mazzoleni, C., Nelson, D., Onasch, T. B., Ottaviani, M., Pekour, M., Prather, K. A., Sedlacek, A., Senum, G., Setyan, A., Shilling, J.E., Shrivastava, M., Song, C., Springston, S. R., Subramanian, R., Tomlinson, J., Wallace, W., Wang, J., Worsnop, D. R., Zelenyuk, A., and Zhang, Q.: Overview of the 2010 Carbonaceous Aerosol and Radiative Study (CARES), submitted, Atmos. Chem. Phys., 2011. 